\title{
Depression in Late Life: Review and Commentary
}

\author{
Dan G. Blazer
}

\author{
Department of Psychiatry and Behavioral Sciences and Center for the Study of Aging, \\ Duke University Medical Center, Durham, North Carolina.
}

\begin{abstract}
Depression is perhaps the most frequent cause of emotional suffering in later life and significantly decreases quality of life in older adults. In recent years, the literature on late-life depression has exploded. Many gaps in our understanding of the outcome of late-life depression have been filled. Intriguing findings have emerged regarding the etiology of late-onset depression. The number of studies documenting the evidence base for therapy has increased dramatically. Here, I first address case definition, and then I review the current community- and clinicbased epidemiological studies. Next I address the outcome of late-life depression, including morbidity and mortality studies. Then I present the extant evidence regarding the etiology of depression in late life from a biopsychosocial perspective. Finally, I present evidence for the current therapies prescribed for depressed elders, ranging from medications to group therapy.
\end{abstract}

Depression ... so mysteriously painful and elusive ... remains nearly incomprehensible to those who have not experienced it in its extreme mood, although the ... "blues" which people go through occasionally ... are of such prevalence that they do give many individuals a hint of the illness in its catastrophic form.

\section{William Styron, from his book Darkness Visible (1, p. 7)}

$\mathrm{D}$ EPRESSION is perhaps the most frequent cause of emotional suffering in later life and significantly decreases quality of life in older adults (2-7). In recent years, the literature on late-life depression has exploded. Excellent North American epidemiological studies from the 1980s and early 1990s have been complemented by more recent reports from other countries (2,4,8-12). Many gaps in our understanding of the outcome of late-life depression have been filled (13-15). Intriguing findings have emerged regarding the etiology of late-onset depression (16-18). The number of studies documenting the evidence base for therapy has increased dramatically $(19,20)$. In this review, I first address case definition, and then I review the current community- and clinic-based epidemiological studies. Next I address the outcome of late-life depression, including morbidity and mortality studies. Then I present the extant evidence regarding the etiology of depression in late life from a biopsychosocial perspective $(6,21)$. Finally, I present evidence for the current therapies prescribed for depressed elders, ranging from medications to group therapy. Given the plethora of literature, important (though on my view not critical) studies have necessarily been omitted, yet the current review reflects the astounding advance of our database since I reviewed the subject in 1989 (22).

\section{Case Definition}

Clinicians and clinical investigators do not agree as to what constitutes clinically significant depression, regardless of age, nor is there universal agreement about how depression should be disaggregated into its component subtypes. The subtypes most cogent to late-life depression are reviewed in the paragraphs that follow. (Because of space limitations, bereavement and bipolar disorder have been omitted from this review.) There is considerable overlap across these subtypes, as the differentiations often reflect particular orientations toward dissecting the syndrome, that is, different ways of "slicing the pie." When the factor structure for the range of depressive symptoms is examined across the life cycle, there are no major differences between Caucasians and African Americans (23), between men and women $(4,23)$, or between older and younger adults $(4,24)$.

Major depression is diagnosed in the Diagnostic and Statistical Manual, Fourth Edition (DSM-IV), when the older adult exhibits one or both of two core symptoms (depressed mood and lack of interest) along with four or more of the following symptoms for at least 2 weeks: feelings of worthlessness or inappropriate guilt; diminished ability to concentrate or make decisions; fatigue; psychomotor agitation or retardation; insomnia or hypersomnia; significant decrease or increase in weight or appetite; and recurrent thoughts of death or suicidal ideation (25). The symptoms of moderate to severe depression presented to the clinician are similar across older adults and persons in midlife if there are no comorbid conditions (26). However, there may be subtle differences by age. For example, melancholia (symptoms of noninteractiveness and psychomotor retardation or agitation) appears to have a later age of onset than nonmelancholic depression in clinical populations, with psychomotor disturbances being more distinct in older persons $(27,28)$.

Minor, subsyndromal, or subthreshold depression is diagnosed according to the Appendix of DSM-IV when one of the core symptoms just listed is present along with one to three additional symptoms (25). Other operational definitions of these less severe variants of depression include a score of $16+$ on the Center for Epidemiologic Studies Depression Scale (CES-D) (29) but not meeting criteria for major depression (10), a primarily biogenic depression not meeting criteria for major depression yet responding to antidepressant medication (30), or a score of 11-15 on the CES-D (31) and therefore not meeting the CES-D criteria for clinically significant depression, that is, 
subthreshold depression. Minor depression variously defined has been associated with impairment similar to that of major depression, including impaired physical functioning, disability days, poorer self-rated health, use of psychotropic medications, perceived low social support, female gender, and being unmarried $(10,31)$.

Other investigators have suggested a syndrome of depression without sadness, thought to be more common in older adults $(32,33)$, or a depletion syndrome manifested by withdrawal, apathy, and lack of vigor (34-36). Dysthymic disorder is a long-lasting chronic disturbance of mood, less severe than major depression, that lasts for 2 years or longer (25). It rarely begins in late life but may persist from midlife into late life $(37,38)$. The aforementioned list is actually truncated from all the different potential subtypes of depression that have been suggested, both past and present. Modern psychiatry has been criticized for its tendency to split syndromes into so many different subtypes without adequate empirical (especially biological) data to justify such splitting (39). One investigator has suggested that the only meaningful split of the depressive spectrum is a split between the more physical symptoms of depression (such as anhedonia, agitation, and perhaps some of the symptoms of executive dysfunction, see the paragraphs that follow) and the more psychological symptoms (40).

Depression in late life is frequently comorbid with other physical and psychiatric conditions, especially in the oldest old (41). For example, depression is common in older patients recovering from myocardial infarction and other heart conditions $(41,42)$, and in those suffering from diabetes (43), hip fracture (44), and stroke (45). In community-dwelling Mexican American elders, depression was associated with diabetes, arthritis, urinary incontinence, bowel incontinence, kidney disease, and ulcers (a profile different from Caucasians, who exhibit comorbidities such as hip fracture and stroke) (46). Major depression is generally thought to be present in approximately $20 \%$ of Alzheimer's patients (47-49). In some studies, however, the rates are much lower $(1-5 \%)(50)$. Depressive symptoms may be common even in elders with mild dementia of the Alzheimer's type (51).

Some differences have been reported between early onset (first episode before the age of 60) and late onset (first episode after the age of 60) depression. Personality abnormalities, a family history of psychiatric illness, and dysfunctional past marital relationships were significantly more common in early onset depression (52). However, when severity, phenomenology, history of previous episode, and neuropsychological performance were compared, there were no differences between early onset and late onset depression in elderly people (52).

Interest in differentiating early- versus late-onset depression in late life has arisen in large part because some people have speculated that contributors to etiology may vary by age of onset. For example, vascular depression (depression proposed to be due to vascular lesions in the brain) may be much more common with late-onset depression, and the clinical presentation may differ, even if only in subtle ways $(16,47,53)$. Severely depressed older adults exhibit impairment in set shifting, verbal fluency, psychomotor speed, recognition memory, and planning (executive cognitive function) (54). The clinical presentation of elderly patients with this "depression-executive dysfunction syndrome" is characterized by psychomotor retardation and reduced interest in activities but a less pronounced vegetative syndrome than is seen in the depressed without executive dysfunction. The dysfunction consists of impaired verbal fluency, impaired visual naming, and poor performance on tasks of initiation and perseveration $(55,56)$. Vascular depression is associated with absence of psychotic features, less likelihood of a family history, more anhedonia, and greater functional disability when compared with nonvascular depression $(16,47,53,57)$.

Psychotic depression, when contrasted with nonpsychotic depression, occurs in $20-45 \%$ of hospitalized elderly depressed patients (58) and $3.6 \%$ of persons in the community with depression (59). Recently a group of investigators proposed a depression of Alzheimer's disease. In persons who meet criteria for dementia of the Alzheimer's type (25), three of a series of symptoms that includes depressed mood, anhedonia, social isolation, poor appetite, poor sleep, psychomotor changes, irritability, fatigue or loss of energy, feelings of worthlessness, and suicidal thoughts must be present for the diagnosis to be made (60).

\section{Epidemiology of Late-Life Depression}

Depressive symptoms are less frequent (or no more frequent) in late life than in midlife $(2,61,62)$, though some suggest these estimates are biased secondary to "censoring" of population studies of older adults by means of increased mortality among the depressed and difficulty in case finding (63) (see Table 1). In a recent study, the lower frequency of depressive symptoms in elderly people compared with people in midlife was associated with fewer economic hardships and fewer experiences of negative interpersonal exchanges among both older disabled and nondisabled respondents. In addition, religiosity among older disabled adults also accounted for part of the lower frequency (64).

Reports of the prevalence of clinically significant depressive symptoms among community-dwelling older adults range from approximately $8 \%$ to $16 \%(2,4,9,62,65)$. Some suggest that depression may be more frequent among Mexican Americans than among non-Hispanic Caucasians and African Americans. In one study, 25\% of older Mexican Americans scored $16+$ on the CES-D (66). In studies of samples of mixed Caucasians and African Americans, rates are similar $(2,4)$. Nevertheless, African Americans are generally seen by psychiatrists to have fewer depressive symptoms and are much less likely to be treated with antidepressant medications $(67,68)$.

Depressive symptoms are more frequent among the oldest old, but the higher frequency is explained by factors associated with aging, such as a higher proportion of women, more physical disability, more cognitive impairment, and lower socioeconomic status $(41,69)$. When these factors are controlled, there is no relationship between depressive symptoms and age (2). The 1-year incidence of clinically significant depressive symptoms is high in the oldest old, reaching $13 \%$ in those aged 85 years or older (70).

The prevalence estimates of major depression in community samples of elderly people have been quite low, 
Table 1. Representative Studies of the Prevalence and Incidence of Depression in Older Adults

\begin{tabular}{|c|c|c|c|}
\hline Author (Ref.) & Sample and Instrument & Prevalence-Incidence Estimate & Comments \\
\hline Berkman et al. (4) & $\begin{array}{l}\text { Community sample of adults } 65+y \text { of } \\
\text { age in New Haven, using the CES-D }\end{array}$ & $\begin{array}{l}\text { 1-wk prevalence estimate of } 16 \% \mathrm{w} / \text { clinically } \\
\text { significant depressive symptoms }\end{array}$ & \\
\hline Blazer et al. (2) & $\begin{array}{l}\text { Community sample of adults } 65+y \text { of } \\
\text { of age in urban and rural NC, using } \\
\text { the CES-D }\end{array}$ & $\begin{array}{l}\text { 1-wk prevalence estimate of } 9 \% \mathrm{w} / \text { clinically } \\
\text { significant depressive symptoms }\end{array}$ & $\begin{array}{l}\text { No differences with increasing age when } \\
\text { confounding variables such as gender } \\
\text { and functional status were controlled } \\
\text { No racial differences }\end{array}$ \\
\hline $\begin{array}{l}\text { Weissman et al. ( } 8 \text { ) } \\
\text { Eaton et al. (74) }\end{array}$ & $\begin{array}{l}\text { Community sample of adults } 65+\text { y of } \\
\text { age in } 5 \text { U.S. communities, both } \\
\text { urban and rural, using the DIS }\end{array}$ & $\begin{array}{l}\text { Overall estimate of the prevalence of major } \\
\text { depression was } 1.4 \% \text { in women and } 0.4 \% \\
\text { in men; estimate of incidence } 0.15 \% \text { overall }\end{array}$ & \\
\hline Steffens et al. (12) & $\begin{array}{l}\text { Community sample of adults } 65+\text { y of } \\
\text { age in Cache County, UT, using } \\
\text { modified DIS }\end{array}$ & $\begin{array}{l}\text { Overall estimate of the prevalence of major } \\
\text { depression was } 4.4 \% \text { in women and } \\
2.7 \% \text { in men }\end{array}$ & \\
\hline Beekman et al. (10) & $\begin{array}{l}\text { Community sample of adults } 65+\mathrm{y} \text { of } \\
\text { age in The Netherlands }\end{array}$ & $\begin{array}{l}\text { Overall estimate of the prevalence of major } \\
\text { depression was } 2 \% \text { and of minor } \\
\text { depression was } 12.9 \%\end{array}$ & \\
\hline Koenig et al. (76) & $\begin{array}{l}\text { Hospitalized sample of VA subjects, } \\
\text { using the DIS }\end{array}$ & $\begin{array}{l}\text { Overall estimate of the prevalence of major } \\
\text { depression was } 11.5 \%, \mathrm{w} / \text { an additional } 23 \% \\
\text { experiencing significant depressive symptoms }\end{array}$ & \\
\hline Parmelee et al. (80) & $\begin{array}{l}\text { LTC residents, using a DSM-IIIR } \\
\text { checklist }\end{array}$ & $\begin{array}{l}\text { Overall estimate of the prevalence of major } \\
\text { depression was } 12.4 \% \text {, w/ an additional } 35 \% \\
\text { experiencing significant depressive symptoms }\end{array}$ & \\
\hline
\end{tabular}

Notes: CES-D = Center for Epidemiologic Studies Depression Scale; DIS = Diagnostic Interview Schedule; VA = Veterans Administration; DSM = Diagnostic and Statistical Manual; LTC $=$ long-term care.

ranging from $1 \%$ to $4 \%$ overall, with higher prevalence among women yet with no significant racial or ethnic differences $(3,9,11,12)$. Estimates for dysthymia and minor depression are somewhat higher, with the same pattern of distribution across sex and race or ethnicity. In the North Carolina Epidemiologic Catchment Area (ECA) Study, in which the Diagnostic Interview Schedule (DIS) was used (71), the prevalence estimate was $0.8 \%$ for major depression, $2 \%$ for dysthymia, and $4 \%$ for minor depression (3). Prevalence in the ECA studies overall in the elderly population was $1.4 \%$ in women and $0.4 \%$ in men (8). The prevalence of major depression in the Cache County, Utah, study of community-dwelling elderly persons was $4.4 \%$ in women and $2.7 \%$ in men (12). In Liverpool, investigators estimated $2.9 \%$ of elders with major depression and $8.3 \%$ with minor depression (72). In The Netherlands, investigators found $2.0 \%$ of older persons with major depression and $12.9 \%$ with minor depression (10). In Sweden, prevalence of major depression in the community was higher among the oldest old, from $5.6 \%$ at the age of 70 to $13 \%$ at the age of 85 (73).

In the United States, the estimate of incidence (new cases over a year) of major depression from the ECA overall was 3 per 1000, with a peak in subjects in their fifties (74). The incidence of major depression in elderly people was $0.15 \%$, similar to the rate in younger age groups $(70,74,75)$. In a study from Sweden, the incidence of major depression was 12 per 1000 person-years in men and 30 per 1000 person-years in women between the ages of 70 and 85 . The incidence increased from 17 per 1000 person-years between the ages of 70 and 79 to 44 per 1000 person-years between 79 and 85.

The prevalence estimates for major depression among older adults hospitalized for medical and surgical services is $10-12 \%$, with an additional $23 \%$ experiencing significant depressive symptoms (76). Major depression affects 5-10\% of older adults who visit a primary care provider (77-79). For example, in one study among 247 subjects in a primary care setting, $9 \%$ were diagnosed with major depression, $6 \%$ with minor depression, and $10 \%$ with subsnydromal depression. Fifty-seven percent of these depressed patients experienced active depression at 1-year follow-up (77).

In one large study of a long-term care (LTC) facilility, $12.4 \%$ experienced major depression and $35 \%$ experienced significant depressive symptoms (80). In another study, depression was found in $20 \%$ of patients admitted to a LTC facility. Incidence of major depression at 1 year was $6.4 \%$ (81). In another study of an LTC facility, prevalence of major depressive disorder among testable subjects was $14.4 \%$ (15\% could not be tested) and prevalence of minor depression was $17 \%$. Less than $50 \%$ of cases were recognized by nursing and social work staff (82). Recognition and treatment in LTC facilities for depression is consistently poor across studies. For example, only $55 \%$ of depressed patients in one LTC facility received antidepressant therapy, and $32 \%$ of those received inadequate doses (83). Screening LTC patients for depression, such as by using the Geriatric Depression Scale (84), can increase the frequency of treatment or referral by primary care physicians in LTC (85).

\section{Outcome of LATE-Life Depression}

\section{Course of Late-Life Depression}

A 6-year follow-up of community dwelling older adults in The Netherlands illustrates the chronicity of late-life depression. Among those with clinically significant depressive symptoms, $23 \%$ remitted, $44 \%$ tracked an unfavor- 
able but fluctuating course, and 33\% tracked a severe chronic course. In the subthreshold group, $25 \%$ experienced a chronic course. Thirty-five percent of the major depressives and $52 \%$ of the dysthymics experienced a chronic course (13).

Major depression in older persons over longer follow-up periods exhibits a chronic remitting course in most clinical studies (86-91). In a 6-year follow-up of elderly depressives, $31 \%$ recovered and remained well, $28 \%$ suffered at least one relapse but recovered, $23 \%$ only partially recovered, and $17 \%$ remained depressed throughout the follow-up (86). In another study, among a group of elderly depressed patients (many of whom were medically ill) followed for 1 year, $35 \%$ had good outcome, $48 \%$ had either remittance and recurrence or remained continuously ill, $3 \%$ developed dementia, and $14 \%$ died (87). In a follow-up of younger subjects who experienced early-onset severe depression and survived into late life (follow-up for 25 years), only $12 \%$ remained continuously well in one study, with neurotic and endogenous depression exhibiting similar outcomes (92). These findings are similar to those in studies of persons in young adulthood and midlife $(93,94)$. Elderly depressed outpatients without significant comorbid medical illness or dementia and who are treated optimally may exhibit a much better outcome, with over $80 \%$ recovering and remaining well throughout follow-up (90). In contrast, elders with a lack of instrumental and social support and poor selfrated health experience a longer time to remission (95).

\section{The Impact of Medical Comorbidity,}

\section{Functional Impairment, and Cognitive Impairment}

Medical comorbidity, functional impairment, and comorbid dementing disorders all adversely influence outcome of depression. Depression, in turn, adversely affects the outcome of the comorbid problems. Depression is a major cause of weight loss in late life (96). Depression is frequently associated with chronic medical illnesses such as cardiovascular disease, and it can complicate the course of these illnesses (97). In one study, older patients with depression following a myocardial infarction were much more likely to die in the first 4 months after the event (26\% vs 7\%) (98). Depression in late life was an independent risk factor for heart failure among elderly women but not among elderly men in another study $(99,100)$. In another study, depression was associated with a decrease in bone mineral density in controlled analyses in people aged 65 years or older (risk factors for osteoporosis) $(101,102)$. Finally, latelife depression has been found to be a risk for poor self-rated health over time (103).

Few mechanisms for these associations have been identified at present, yet some have been theorized and explored. Platelet activation is increased in elderly depressed patients, especially those with the serotonin-transporterlinked promotor region 5-HTTLPR polymorphism (this group had significantly higher platelet factor 4 and betathromboglobulin levels). This finding suggests how some depressed patients may be at greater biological risk for morbidity and mortality with ischemic heart disease (104). Poor appetite can lead to low body mass index associated with late-life depression and subsequent frailty and failure to thrive $(41,105,106)$. In an 18 -month prospective study of community-dwelling older adults (including both spousal caregivers of dementia patients and noncaregiving controls), those with chronic, mild depressive symptoms had poorer T-cell responses to two mitogens from baseline to follow-up. In addition, among those with depression, older age was associated with the poorest blastogenic response to mitogens at follow-up. The stress of caregiving may have augmented this response. Older patients with depression have higher levels of the cytokine interleukin 6 , indicating increased inflammatory activity, which may be linked to increased bone resorption (or depressed patients may be more sedentary, leading to increased resorption rates), thus increasing the risk for hip fracture $(107,108)$.

Depression is clearly associated with functional impairment $(2,109,110)$ and effects disability status over time $(55,111,112)$. In one study, depression increased the risk for activities of daily living disability and mobility disability over 6 years by $67 \%$ and $73 \%$, respectively (113). Even less severe symptoms of depression are associated with functional decline, such as "depression without sadness" (32). Disability is also a risk factor for depression $(114,115)$. A number of explanations have been proposed. Physical disability appears to lead to higher numbers of negative life events. In addition, physical disability can lead to restriction of valued social or leisure activities, isolation, and reduced quality of social support (116). If disability can be improved, then depression may be relieved. Yet another explanation is that depression as a state is disabling. For example, executive-type cognitive impairments caused by depression may explain why depressed persons are more disabled $(55,117)$. When depression accompanies stroke, functional outcome is compromised as well (118).

Functional decline is not inevitable following depression, however. A diagnosis of depression in older primary care patients in one study led to poorer self-reported role functioning but not to poorer self-reported physical functioning (119). Instrumental support provided to elders (such as helping with tasks) was generally protective against worsening performance on instrumental abilities of daily living among elderly patients with recurrent unipolar depression. Subjective and structural dimensions of social support protected the most severely depressed elderly patients against the loss of basic maintenance abilities (a clinical sample) (120).

Severe depression with cognitive impairment, even when the cognitive impairment remits, is a risk for Alzheimer's disease (AD) over 5 years (14). Early depressive symptoms among subjects with minimal cognitive impairment (MCI) may represent a preclinical sign and should be considered a risk factor for impending $\mathrm{AD}$ or vascular dementia (121). Depression further complicates the course of AD by increasing disability and physical aggression and leading to greater caregiver depression and burden (122-124). However, in a follow-up study, depressive symptoms among $\mathrm{AD}$ patients have higher rates of spontaneous resolution without requiring intensive drug treatment than among vascular dementia patients, in whom depressive symptoms are more persistent and refractory to drug treatment (121). 


\section{Nonsuicide Mortality}

Nonsuicide mortality is a significant adverse outcome resulting from late-life depression. In a review of 61 reports from 1997 to 2001, 72\% demonstrated a positive association between depression and mortality in elderly people (15). Another reviewer reported that, in 23 mortality studies of depression (subjects $65+$ years of age), the pooled odds of dying if subjects were depressed were 1.75. A longer followup predicted smaller effect size. Both severity and duration of depressive symptoms predict mortality in the elderly population in these studies (125). Representative extant studies include summary data from the ECA study, in which the investigators found a fourfold increase in the odds of dying over a follow-up of 15 months if persons 55+ years of age experienced a mood disorder (111). Other cross-national studies of a positive association were found in Australia and Japan $(126,127)$. Among community-dwelling persons in The Netherlands, both major and minor depression increased the risk for cardiac mortality in subjects with and without baseline cardiac disease (128). The association between depression and mortality holds in many of these studies, despite the addition of potentially confounding variables. For example, in one study, high levels of depressive symptoms independently predicted mortality in a study where demographics, medical comorbidity, smoking, and body mass index were controlled (129). In studies from North Carolina and New York, however, investigators failed to find an association $(130,131)$. One reason for the lack of association in some studies may be the selection of control variables to be included, especially chronic disease and functional impairment. For example, in a study of the North Carolina Established Populations for Epidemiologic Study of the Elderly (EPESE) cohort, the unadjusted relative odds of mortality among depressed subjects at baseline was 1.98 . These odds moved toward unity as other risk factors were controlled, such as chronic disease, and health habits, cognitive impairment, functional impairment, and social support were added to the model (132). Therefore, the specific variables controlled in mortality studies may determine the association between depression and mortality.

The effect of depression on mortality may vary by sex. In elderly Japanese American men but not women, depressive symptoms were a risk for mortality in the physically healthy (133). In another study, depressive symptoms were a significant risk factor for cardiovascular but not cancer mortality in older women $(134,135)$. In a controversial report, investigators found that subthreshold depression (CES-D scores of 12-16) was not associated with mortality in men but was negatively related to 3 -year mortality in women (odds ratio $=.6$ ) (136). In other words, mild depressive symptoms were protective in this highly controlled analysis of community-based data.

\section{Suicide}

Suicide frequency in the $65+$ age group in the United States was $16.9 / 100,000$ per year in $1998(137,138)$. The frequency for white men increased with age, reaching 62/ 100,000 in the $65+$ age range. Frequency among nonwhite men was highest in young adulthood and was slightly higher in midlife among women. The association of depression and suicide has been well established in the literature across the life cycle (138-143). Elderly persons attempting suicide are also more likely to be widow(er)s, live alone, perceive their health status to be poor, experience poor sleep quality, lack a confidant, and experience stressful life events, such as financial discord and interpersonal discord $(138,143)$. The most common means of committing suicide is the use of voluntary drug ingestion. Whereas completed suicides increase with age, suicidal behaviors do not increase (144). There are approximately four attempts for each completed suicide in late life compared with 10 or more attempts per completed suicide earlier in life (145). Suicidal ideation is high among older adults, ranging from $5 \%$ to $10 \%$ of the population of older adults $(138,140)$.

\section{Health Services Utilization}

Late-life depression leads to increased use of hospital and outpatient medical services (146-148). For example, having depressive symptoms was associated with a $19 \%$ increase in the number of outpatient encounters and a $30 \%$ increase in total outpatient charges in a Minnesota health maintenance organization. Taking antidepressant medications was associated with a $32 \%$ increase in total outpatient charges but was not significantly associated with number of outpatient encounters. Depressive symptoms and antidepressant therapy were not significantly associated with inpatient utilization or charges (149). Older persons are quite likely to use antidepressant medications, most of which are prescribed for depression (68). In a community sample in North Carolina, $14.3 \%$ of Caucasians and 5\% of African Americans used antidepressants in 1996 (in controlled analyses, Caucasians were 3.8 times more likely to use antidepressants than African Americans).

\section{ETIOLOGY}

\section{Biological}

Any discussion of the biological etiology of depression must begin with medical illness, for depression among the medically ill in late life is almost ubiquitous, as just documented. In addition to the association of depression with dementing disorders, cardiovascular disease, and hip fractures, among patients with Parkinson's disease, $20 \%$ meet criteria for major depression and $21 \%$ meet it for minor depression (150). Depression has been associated with pain in institutionalized elderly people (151) and is also common among homebound elders with urinary incontinence (152). Both alcohol dependence and major depression pose significant risk for the development of the other disorder at 1-year follow-up (153). In a series of recently reported studies, diastolic hypotension was associated with low positive affect, whereas systolic hypertension was associated with a positive affect. Use of antihypertensive medication was independently associated with lower positive affect in elderly people (154). Male veterans who were hospitalized during World War II for head injury were more likely to report major depression in subsequent years (155).

Great interest has arisen in recent years to search for genetic susceptibility to mood disorders across the life cycle (156). In a community sample of elderly twins, genetic 
influences accounted for $16 \%$ of the variance in total depression scores on the CES-D and $19 \%$ of psychosomatic and somatic complaints. In contrast, genetics contributed a minimal amount to the variance in reports of depressed mood and psychological well-being (157). Yet the likelihood of identifying a family history of mood disorder in a clinically depressed older adult is lower than for persons in midlife. In a clinical study, the risk for immediate relatives of patients with depression whose onset occurred after age 50 was $8.3 \%$ compared with $20.1 \%$ for relatives of patients whose onset occurred at a younger age (158).

Attention has been directed to specific genetic markers for late-life depression. Given the great interest in the $\varepsilon 4$ allele of the apolipoprotein $\mathrm{E}$ gene, a number of studies have focused on this susceptibility gene for Alzheimer's disease. No association was found in a community sample between $\varepsilon 4$ and depression (159). In another study, hyperintensities in deep white matter but not in the periventricular white matter were associated with depressive symptoms, especially in elders carrying the $\varepsilon 4$ allele (160). Other investigators have concentrated on genes possibly associated with vascular lesions in the central nervous system. In one study, patients with late onset depression had an increased rate of the C677T mutation of the MTHFR (methylene tetrahydrofolate reductase) enzyme. This mutation may place older persons at risk for vascular depression (57). CADASIL (cerebral autosomal dominant arteriopathy with subcortical infarcts and leukoencephalopathy) is a disease of the notch 3 gene. Depression is one of the initial symptoms in this condition, suggesting that genetic polymorphisms or mutations may predispose older adults to vascular depression. This genotype, however, is rare $(161,162)$.

Much attention has been directed to vascular risk for latelife depression, and this attention dates back at least 40 years, although the advent of magnetic resonance imaging boosted interest considerably $(86,163-166)$. Recent studies suggest that vascular lesions in selected regions of the brain may contribute to a unique variety of late-life depressionhence the interest in vascular depression as just discussed. The vascular depression impairments resemble impairments exhibited in frontal lobe syndromes. Magnetic resonance imaging of depressed patients has revealed structural abnormalities in areas related to the cortical-striatal-pallidalthalamus-cortical pathway (167), including the frontal lobes (168), caudate (169), and putamen (170). These circuits are strongly implicated in the development of spontaneous performance strategies demanded by executive tasks. Recent interest has also focused on a smaller size of the orbital frontal cortex in late-life depression (171). In addition, left hippocampal volume has been found to be smaller in depressed elders who develop dementia over time (172). The frontal white matter (not gray matter) lesions in late-life depression are associated with increased myoinositol-creatinine and choline-creatinine ratios. These changes may reflect biological changes in nonneural (glial) tissue, which in turn affects synaptic activity (166).

Serotonin activity, specifically, $5 \mathrm{HT}_{2 \mathrm{~A}}$ receptor binding, decreases dramatically in a variety of brain regions through midlife, but there is less decrease from midlife to late life. These $5 \mathrm{HT}_{2 \mathrm{~A}}$ receptors in normal healthy subjects de- creased markedly from young adulthood to midlife (70\% from the levels at age 20 through the fifth decade), and then leveled off as age advanced. Receptor loss occurred across widely scattered regions of the brain (anterior cingulated, occipital cortex, and hippocampus) (18). The relationship of serotonin depletion can also be studied indirectly by the study of radioisotope-labeled or tritiated imipramine binding (TIB) sites. There is a significant decrease in the number of platelet-TIB sites in elderly depressed patients, compared with elderly controls and individuals suffering from Alzheimer's disease (173).

In aged monkeys (Macaca mulatta), significant agerelated decreases in $5 \mathrm{HT}_{1 \mathrm{~A}}$ receptor binding were observed only in the frontal and temporal cortices. In the hippocampus, although $5 \mathrm{HT}_{1 \mathrm{~A}}$ receptor binding indicated nonsignificant age-related changes, the degree of displacement when binding to a receptor agonist was decreased in the aged monkeys. This finding suggests that age-related impairment of $5 \mathrm{HT}_{1 \mathrm{~A}}$ receptor response might be related to the reduced efficacy of antidepressant therapy in elderly patients with depression (174).

Endocrine changes have also been associated with latelife depression. Although the dexamethasone suppression test was long ago ruled out as a diagnostic test for depression, nonsuppression of cortisol is associated with late-life depression compared with age-matched controls (175). Depression is associated with hypersecretion of corticotropinreleasing factor (CRF), which is thought to mediate sleep and appetite disturbances, reduced libido, and psychomotor changes (176). Aging is associated with an increased responsiveness of adrenocorticotropic hormone (ACTH), cortisol, and dehydroepiandrosterone sulfate (DHEA-S) to CRF (177). Low levels of DHEA have been associated with higher rates of depression and a greater number of depressive symptoms in community-dwelling older women (178). Total testosterone levels were lower in elderly men with dysthymic disorder than in men with major depressive disorder and men without depressive symptoms in another study (179). However, the efficacy of testosterone in treating depression has not been established (180). Depression has also been associated with postprandial systolic hypotension (181). Hormone replacement in women has been associated with improvements in mood (182).

\section{Psychological}

Behavioral, psychodynamic, and cognitive aberrations have all been suggested as causes of late-life depression. Three examples will illustrate these proposed etiologies. The behavior of learned helplessness, originally used to described the increasingly passive behavior of dogs produced by inescapable shock, has been expanded to explain depressive symptoms across the life cycle, suggesting that the cause of depression is the expectation that initiating action in a continually stressful environment is futile $(6,183$, 184). The association of depression with severe or frequent adverse life events could be interpreted in part as a behavioral response to continued adverse stressors. Depression in old age has been associated with emotional abuse and neglect during childhood, as well as relational stress and problem behavior of significant others during late adulthood 
(especially high when many events reported during adulthood and late adulthood) (185). In a meta-analysis, the number of total negative life events and daily hassles was associated with depression in elderly people (186). Severe events show the largest relative risk, but ongoing difficulties account for the most episodes. The association of severe events with onset tends to be stronger in first than in recurrent episodes. Mild events can trigger a recurrence but not a first episode, suggesting that once the development of the behavior of "depression" follows a stressor, the triggers for subsequent episodes of depression need not be severe thereafter (187).

According to one psychodynamic theory, the search for restitution secondary to the inevitable losses in late life is a major developmental task for aging individuals and a depression-like syndrome may appear, a "depletion syndrome," when this task is not accomplished successfully. If one lives long enough, the inevitable object loss, body change, and disease lead to a state of both internal and external depletion $(6,188)$. A more recent yet controversial theory complements the depletion theory, suggesting that successful aging is associated with "selective optimization with compensation" (189). This model is based on a recognition by the elder of the realities of aging, especially the losses. Such recognition leads to selection of realistic activities, optimization of those activities, and compensation for lost activities, which in turn leads to a reduced and transformed life.

Perhaps the most dominant psychological model of depression is the model of cognitive distortions (190). In a case-control study, patients with major depression perceived greater negative impact of life events than patients with dysthymic disorder and healthy controls (191). The interpretation of life events is the key to understanding depression under this theory. Cognitions may be distorted such that the elder has unrealistic expectations, overgeneralizes certain adverse events, overreacts to events, and personalizes events. Perceived negative interpersonal events are associated with depression in elders, particularly in those who demonstrate a high need for approval and reassurance in the context of interpersonal relationships. In contrast, negative achievement events are associated with depression in those who placed a heavy emphasis on personal success and control. This conceptualization is consistent with the diathesis-stress model, namely that negative experience best predicts depression when a specific type of event affects a personal vulnerability $(192,193)$.

\section{Social}

The association between late-life depression and impaired social support has been established for many years. In a community study in Hong Kong (194), impaired social support and depression were associated (including network size, network composition, social contact frequency, satisfaction of social support, and instrumental-emotional support). Impaired social support is associated with poorer outcome of depression in older men but not older women (195). In female caregivers of demented elderly people, the prevalence rate of depressive disorders reaches $45-47 \%$, and these women are twice as likely to use psychotropic drugs
$(196,197)$. Loneliness may be a key factor in depression among caregivers (198). Some have attempted to couple the theory of social disengagement with aging (much debated in the literature) with depression, suggesting that some symptoms of depression, such as lack of social interest and greater self-involvement, mirror attributes of older adults according to Disengagement Theory $(199,200)$. Other factors being equal, it is probable that elders who are less socially engaged are more depressed. For example, elders who stopped driving had a greater risk of worsening depressive symptoms (201).

\section{Spiritual and Existential}

Religious practice is associated with less depression in elderly Europeans (EURODEP), both on the individual and the national level. This is especially true when religious practice is embedded within a traditional value orientation (202). Some investigators have proposed that "religious coping" (subjects perceiving that religion is the most important factor in coping) is associated with improved emotional and physical health $(203,204)$. They found that religious coping was associated with a decrease in certain types of depressive symptoms, including loss of interest, feelings of worthlessness, withdrawal from social interactions, loss of hope, and other cognitive symptoms of depression. Religious coping was not associated with a reduction in somatic symptoms.

\section{Diagnostic Evaluation}

Much of the diagnostic workup of late-life depression derives from what we know about symptom presentation and etiology (see Table 2). Basically, the diagnosis is made on the basis of a history augmented with a physical and finetuned by laboratory studies. There is no biological marker or test that makes the diagnosis, though for some subtypes of depression, such as vascular depression, the presence of subcortical white matter hyperintensities on magnetic resonance imaging scanning are critical to the diagnosis $(6,185)$.

Screening is beneficial when standardized screening scales such as the Geriatric Depression Scale (GDS) or the CES-D are used $(29,84,205)$. Screening in primary care is critical. Not only is the frequency of depression high, but suicidal ideation is high as well. The prevalence of serious suicidal ideation in one primary care setting was $1 \%$ and the prevalence approaches 5\% among older adults who report significant symptoms of depression $(206,207)$. However, the documented success of screening has been mixed in extant studies. Internists tend to accept responsibility for treating late-life depression but perceive their clinical skills as inadequate and are frustrated with their practice environment (207). Nearly all studies of treatment efficacy with pharmacotherapy or psychotherapy focus on older adults with uncomplicated major depression, which may apply to less than $15 \%$ of the depressed people in primary care (208). Primary care physicians were informed of patient-specific treatment recommendations for depressed patients $60+$ years of age in one controlled study. The patients of physicians in the intervention group were more likely to be diagnosed with depression and prescribed antidepressant medications, 
Table 2. Diagnostic Workup of the Depressed Older Adult

\begin{tabular}{|c|c|}
\hline Routine & Elective \\
\hline $\begin{array}{l}\text { Screening for significant depressive } \\
\text { symptoms (using a standardized } \\
\text { screening scale such as the CES-D } \\
\text { or GDS)* }\end{array}$ & $\begin{array}{l}\text { MRI to establish the diagnosis } \\
\text { of vascular depression }\end{array}$ \\
\hline $\begin{array}{l}\text { Present and past history, including } \\
\text { history from a family member- } \\
\text { include assessment of nutritional } \\
\text { status and functional status and } \\
\text { current medications }^{\dagger}\end{array}$ & $\begin{array}{l}\text { Vitamin } \mathrm{B}_{12} \text { and folate } \\
\text { assays when vitamin } \\
\text { deficiency is suspected }\end{array}$ \\
\hline Screen for cognitive functioning ${ }^{\ddagger}$ & $\begin{array}{l}\text { Polysomnography if significant } \\
\text { sleep abnormalities } \\
\text { cannot be explained }\end{array}$ \\
\hline $\begin{array}{l}\text { Routine laboratory tests, esp. chemistry } \\
\text { screen and electrocardiogram } \\
\text { if antidepressants are to be } \\
\text { prescribed }^{\S}\end{array}$ & $\begin{array}{l}\mathrm{T}_{3} \text { and } \mathrm{T}_{4} \mathrm{TSH} \text { to screen for } \\
\text { undiagnosed thyroid } \\
\text { dysfunction }\end{array}$ \\
\hline
\end{tabular}

though the outcome of the depression was no better for the intervention group than for the control group (209).

Cognitive status should be assessed with the Mini-Mental State Examination (MMSE), given the high likelihood of comorbid depression and cognitive dysfunction (210). Nutritional status is most important to evaluate in the depressed elder, including height, weight, history of recent weight loss, lab tests for hypoalbuminemia, and cholesterol, given the risk for frailty and failure to thrive in depressed elders, especially the oldest old $(41,106)$. General health perceptions (211) as well as functional status (activities of daily living) should be assessed for all depressed elderly patients $(212,213)$. Other factors critical to assess in the diagnostic workup include social functioning (214), medications (many prescribed drugs can precipitate symptoms of depression), mobility and balance, sitting and standing blood pressure, blood screen, urinalysis, chemical screen (e.g., electrolytes, which may signal dehydration) and an electrocardiogram if cardiac disease is present (especially if antidepressant medications are indicated) (41).

\section{Treatment}

\section{Biological}

Antidepressant medications have become the foundation for the treatment of moderate to severe depression in older adults. Virtually all antidepressant medications are equally effective for treating serious major depression across the life cycle $(19,215,216)$. Studies that compare tricyclic antidepressants (TCAs) and selective serotonin reuptake inhibitors (SSRIs) usually find equal efficacy, yet there are fewer side effects with SSRIs (217). Therefore, SSRIs are the treatment of choice $(203,206)$. The antidepressants even appear to be efficacious in subjects with subcortical hyperintensities (vascular depression) $(218,219)$. Although subjects with de- pression and smaller frontotemporal volumes on magnetic resonance imaging were more treatment resistant in one study (220), a number of studies document the efficacy of antidepressant therapy for treating depression in dementia (221-223).

Antidepressants appear less efficacious in treating less severe depression (224). A large study in a primary care setting found that paroxetine showed moderate benefits for depressive symptoms and mental health functioning in elderly patients with dysthymia and more severely impaired elderly patients with minor depression (compared with problem-solving therapy) (225). The overall evidence suggests that antidepressants and counseling have relatively small benefit in these less severe conditions (226). The use of St. John's wort (Hypericum perforatum) has been recommended for less severe depression and, given that it is available over the counter, it is used by mildly depressed older adults (and perhaps some who are more severely depressed). A recent study did not find that St. John's wort was as effective as sertraline in moderately severe major depression (mostly persons in midlife) (227). Nevertheless, this study has been criticized for not focusing on the mildly depressed.

Most of the SSRIs have been demonstrated to be efficacious in elderly people, including the drugs fluoxetine (228), sertraline (229), paroxetine $(217,230)$, citalopram (231), and fluvoxamine (232). (Escitalipram, recently entering the antidepressant market, has not been shown to be specifically efficacious in the elderly population.) Other new-generation antidepressants that have been shown to be efficacious include venlafaxine (233), mirtazapine (234, 235), nefazodone (in a general study of depression), and buproprion $(236,237)$. Nefazodone $(238)$ has not been shown to be specifically efficacious in elderly people, because to date there has been no study of the drug in the elderly population.

In a recent consensus of practicing geriatric psychiatrists, the SSRIs along with psychotherapy are the treatments of choice for late-life depression, along with venlafaxine XR. Buproprion and mirtazapine are alternates (as was electroconvulsive therapy, or ECT, in severe depression). Medication (SSRI plus an antipsychotic, with risperidone and olanzapine being the antipsychotics most commonly recommended) and (or) ECT are the preferred treatments of unipolar psychotic major depression. Medications plus psychotherapy are recommended for dysthymic disorder. Education plus watchful waiting are recommended for minor depression that lasts for less than 2 weeks (antidepressant medication plus psychotherapy are recommended for minor depression if symptoms persist). The preferred antidepressant for treating both major and minor depression is citalopram (20-30 mg) followed by sertraline (50-100 mg) and paroxetine $(20-30 \mathrm{mg})$, with fluoxetine $(20 \mathrm{mg})$ as an alternate. Nortriptyline $(40-100 \mathrm{mg})$ is the preferred tricyclic agent, with desipramine $(50-100 \mathrm{mg})$ as the alternate. The consensus recommendation is to continue an antidepressant 3-6 weeks before a change in medications is made. If little or no response is observed, the consensus is to switch to venlafaxine (75-200 mg). For a first episode of depression with recovery following antidepressant therapy, 1 year of continual therapy is recommended. For two episodes, 2+ years of continual therapy and for three or more episodes, 
$3+$ years of continual therapy are recommended (239), as shown in Table 3.

Many factors may alter the efficacy or the side effects of the antidepressant drugs in late life. For example, estrogen therapy and DHEA have been demonstrated to augment sertraline treatment $(240,241)$. A number of the cytochrome P450 enzymes that metabolize most medications are inhibited by antidepressants, such as CYP3A, CYP2D6, DYP2C, CYP1A2, and CYP2E1. The CYP3A enzymes metabolize $60 \%$ of the medications used today. Fluoxetine is a moderate inhibitor of CYP3A4. Approximately 8-10\% of adults lack the CYP2dD6 enzyme, and paroxetine is a potent inhibitor of this enzyme (which may explain, among some patients treated with paroxetine, the lack of efficacy of analgesics such as codeine that are metabolized by this enzyme). Citalopram and venlafaxine are the "cleanest" of the medications in terms of inhibition of the cytochrome P450 enzymes $(242,243)$.

Elderly inpatients on SSRIs or venlafaxine are at definite risk for developing hyponatremia (39\% in one study) and should have sodium levels checked before and after commencement of antidepressant medications (244). This hyponatremia is due to the syndrome of inappropriate secretion of antidiuretic hormone. Other serious side effects reported with the SSRIs include the risk of falls (no less risk than with the tricyclics in one study) (245), the serotonin syndrome (lethargy, restlessness, hypertonicity, rhabdomyolysis, renal failure, and possible death) (246), and gastrointestinal bleeding (247). Less serious side effects include weight loss, sexual dysfunction, anticholinergic effects (most pronounced with paroxetine), agitation, and difficulty sleeping.

Subjects with psychotic depression respond poorly to antidepressants but well to ECT (248). Many studies have documented the effectiveness of ECT in older adults (249251). Some investigators report the response as good in elderly as in young people (252), whereas others suggest that the response is less optimal in the oldest old (253). In one study using bilateral ECT versus pharmacotherapy, the $65+$ age group had a better response to ECT than younger age groups (254). Memory problems remain the major adverse effect from ECT that affects quality of life. Memory problems are usually transient and clear within weeks following treatment. A relatively new procedure that could replace ECT in some situations is repetitive transcranial magnetic stimulation (rTMS) (255). TMS does not require anesthesia and seizure induction is avoided. Though not studied specifically in elderly people, in one outcome study, patients treated with rTMS compared with ECT responded equally well and their clinical gains lasted at least as long as those with ECT (256). In another study, executive function improved in both middle-aged and elderly depressed subjects with rTMS compared with sham treatments (257).

Investigators with the Alameda County Study explored the association of exercise and depression, controlling for functional status. Among subjects who were not depressed at baseline, those who reported a low activity level were at significantly greater risk for depression at follow-up (258). On the basis of controlled trials, an aerobic exercise training program may be considered an alternative to antidepressants
Table 3. Consensus Treatments of Late-Life Depression

\begin{tabular}{|c|c|}
\hline Diagnosis & Treatment \\
\hline Major depression & $\begin{array}{l}\text { SSRIs plus psychotherapy. Citalopram (20-30 } \\
\mathrm{mg}) \text { first choice, followed by sertraline }(50- \\
100 \mathrm{mg}) \text { and paroxetine }(20-30 \mathrm{mg}) ; 1-\mathrm{y} \\
\text { continued therapy if treatment successful; } \\
\text { ECT if the depression is severe and } \\
\text { unresponsive to antidepressant medications }\end{array}$ \\
\hline $\begin{array}{l}\text { Unipolar psychotic } \\
\text { major depression }\end{array}$ & $\begin{array}{l}\text { SSRIs plus an antipsychotic agent (risperidone } \\
\text { and olanzapine); move quickly to ECT if } \\
\text { therapy not effective }\end{array}$ \\
\hline Dysthymic disorder & SSRIs plus psychotherapy \\
\hline Minor depression & $\begin{array}{l}\text { Education plus watchful waiting for depression } \\
\text { lasting }<2 \mathrm{wk} \text {; SSRIs plus psychotherapy if } \\
\text { symptoms persist }\end{array}$ \\
\hline
\end{tabular}

Note: From Alexopoulos et al. (239). SSRI = selective serotonin reuptake inhibitor; ECT $=$ electroconvulsive therapy.

for treatment of depression in older persons (259). However, the advantages of exercise are not limited to aerobic activities. Unsupervised weight lifting has been found to decrease depressive symptoms up to 20 weeks after induction (260). Light therapy may also be beneficial, especially if the depression follows a seasonal pattern. Thirty minutes of bright light a day improved depression among institutionalized elders in one controlled study (261).

\section{Psychological}

Psychotherapy has received much attention and study as a treatment modality for depressed older adults over the past 20 years. This attention results from the development of "manualized" therapies, such as cognitive behavioral therapy (CBT) and interpersonal therapy (IPT). These therapies can be taught clearly and easily to Masters-level clinicians and can be monitored for accuracy in following the procedures of the therapy. Most of these therapies are short term (12-20 sessions) and therefore much more attractive to third-party payers. In addition, the educational (as opposed to a reflective) posture of the therapist employing manualized therapies is attractive to elders. In one study comparing range of referrals, outcomes, attendance rates, and length of time in therapy between older and younger adults participating in cognitive therapy, there was no significant differences in therapy outcome apart from home adjustment measures where older adults showed greater improvement. Younger adults showed significantly higher rates of nonattendance and had higher dropout rates (262).

Nevertheless, psychotherapy remains an infrequently prescribed therapy for depressed older adults. In a study of general internists, only $27 \%$ said they would refer a depressed older adult for psychotherapy (263). In a sample of primary care elderly patients in Quebec, the acceptability of a therapy was dependent on the severity of symptoms. CBT and cognitive bibliotherapy were rated more acceptable than antidepressants when the symptoms were less severe. Antidepressants were more acceptable than either CBT or bibliotherapy when the patient's symptoms were severe (264).

CBT and IPT have been the most frequently studied of the manualized therapies (20,262-266). Exact mechanisms 
that render CBT and IPT effective, however, remain unclear (267). CBT focuses on thoughts that may perpetuate depression. The therapeutic goal of the therapist is to teach the patient to change these thought patterns or adapt to them. By changing thoughts, people change dysfunctional attitudes as well, and these attitudes are hypothesized to precipitate and perpetuate depressive thoughts (192). Studies increasingly suggest that the more central mechanism for changing thought patterns is the development of metacognition, that is, "stepping back" and responding to negative thoughts as transitory events rather than as inherent aspects of the self (268). In one study comparing CBT and brief psychodynamic therapy to a wait-list control group, all of the treatment modalities led to a comparable and clinically significant reduction of depression (265). Twelve months after the treatment, $58 \%$ of the sample population was depression free, and at 24 months, $70 \%$ was depression free. In another study, older depressed patients were assigned to CBT alone, medication alone, or a combination of medication and CBT (269). Although all groups showed improvement, the combined group showed the greatest improvement.

IPT is a manualized treatment that focuses on four components hypothesized to lead to or maintain depression: grief (e.g., death of a loved one); interpersonal disputes (e.g., conflict with adult children); role transitions (e.g., retirement); and interpersonal deficits (e.g., lack of assertiveness skills). The treatment has been adapted specifically for older adults $(270,271)$. In combination with nortriptyline, IPT has been shown to be an effective treatment for elderly depressed subjects $(90,272,273)$. In one study, investigators achieved an excellent initial response (74\%) with only $15 \%$ recurrence at the end of 1 year (90). Subjects who respond do not tend to relapse over fairly extensive periods (272).

More reflective therapies include psychodynamic therapy, life review therapy, and reminiscence therapy. Cases of successful psychodynamic therapy have been presented in the literature among older adults (274), and in one study psychodynamic therapy was as effective as CBT (275). Given its very nature, however, psychodynamic psychotherapy is most difficult to investigate empirically. In life review therapy, subjects are encouraged to acknowledge past conflicts and consider their meaning. In reminiscence therapy, the focus is more on positive memories in group settings. Both structured and unstructured reminiscence therapy lead to improvement compared with controls, and the structured group did even better (276). In contrast, another study found no improvement over wait-list controls (277). Bibliotherapy emphasizes a skills acquisition approach through select readings from books. For example, subjects may read Feeling Good (278), a self-help book that emphasizes employing cognitive skills to overcome depression. In a series of controlled randomized studies for mild to moderate depression in older adults, bibliotherapy was shown to be efficacious (279-282). Bibliotherapy has advantages for older adults. Elders can read and process the material at their own pace. Fears of stigmatization can be avoided and, for elders with impaired activities of daily living, this intervention does not require as many visits to a therapist (267).
Group therapy is used frequently with older adults, though it is less often studied compared with individual therapy (283). Self-management therapy and education groups were equally effective and superior to wait-list controls in one study (284). CBT and psychodynamic group therapy were more effective than placebo but less effective than tricyclics in other studies $(285,286)$. In a recent study, investigators found that antidepressant medication plus clinical management, either alone or with addition of groupadministered dialectical behavior therapy (skills training and scheduled coaching sessions), found that the medication-dialectical behavior therapy groups had a higher continued remission rate than medications alone $(267,287)$.

\section{Combined Medication and Psychotherapy}

In geriatric patients with recurrent major depression, maintenance treatment with nortriptyline or IPT is superior to placebo in preventing or delaying recurrence. Combined treatment using both appears to be the optimal clinical strategy in preserving recovery (272). Combined treatment with nortriptyline and IPT is also more likely to maintain social adjustment (performance-impaired or not, interpersonal behavior-hypersensitivity, friction-quarreling, satisfaction-loneliness) than treatment with either alone (288).

The PROSPECT (Prevention of Suicide in Primary Care Elderly-Collaborative Trial) is testing whether a trained clinician (a "health specialist") can work in close collaboration with a primary care physician to implement a comprehensive depressive management program including pharmacotherapy and IPT. The goal is to reduce suicidal ideation (289). Older patients with suicidal ideation in the midst of a recurrent episode of major depression respond as well as nonsuicidal patients, yet those with ideation have higher relapse rates during continuation treatment and were more likely to receive augmentation pharmacotherapy (290).

\section{Can Late-Life Depression Be Prevented?}

The extant psychiatric literature suggests virtually no empirical evidence of psychosocial primary prevention. A MEDLINE review of the American Journal of Psychiatry from 1990 to 2001 and the American Journal of Geriatric Psychiatry from 1997 to 2001 did not yield a single empirical study of the primary prevention of depression in the elderly population (or of an intervention strategy that might be considered universal) (291). The few references to primary prevention of late-life depression focused on blood pressure control to prevent cerebrovascular disease as a means of preventing vascular depression (292). In contrast, these journals are replete with articles regarding secondary prevention, that is, the early treatment of depression with medications and psychotherapy to remit depression and prevent its serious consequences as already described $(19,272)$. As already described regarding the PROSPECT study, tertiary prevention (prevention of the serious consequences of late-life depression such as suicide) has received attention as well. The biological emphasis of today's psychiatry coupled with the paucity of empirical studies that document the benefit of primary (or universal) prevention undoubtedly have influenced recent contributions to the literature. 
A recent study among elderly people is directly relevant to primary prevention (293). Elderly subjects who experienced chronic illness were randomly assigned to a classroom intervention, a home study program, and a wait list. Both interventions provided instruction on mind-body relationships, relaxation training, cognitive restructuring, problem solving, communication, behavioral treatment for insomnia, nutrition, and exercise (a multimodal intervention strategy that integrates many approaches to enhancing self-efficacy in elderly people). The home version was delivered by class videotapes and readings. Compared with the control condition, both interventions led to significant decreases in self-reports of pain, sleep difficulties, and symptoms of depression and anxiety. Such nonpharmacological interventions among vulnerable older adults may become increasingly important in our efforts to decrease the burden of depression among older adults.

\section{Future Directions}

In a recent editorial derived from a conference devoted to the diagnosis and treatment of late-life depression, the authors concluded, "Treatment works, but mood disorders in old age remain a big public health issue. Disability, decline, diminished quality of life, demands on care givers and discriminatory reimbursement policies [persist] ... partnerships among researchers, clinicians, governmental agencies, third payers, patients and family members will be essential to further progress in the next 10 years" (294, p. 146). No one can reasonably argue with this conclusion. I would add that perhaps some slight paradigm shifts may be called for as well. For example, we must consider more carefully the boundaries between "true" clinical depression and less severe (perhaps adaptive) depressive symptoms among elders. In addition, the efficacy of antidepressants (which are now used widely) has been amply demonstrated in clinical trials, yet we have not verified the effectiveness of these medications in reducing the burden of depressive symptoms among the populace of older adults and in decreasing the frequency of suicide. Effectiveness studies are critical lest we falsely equate use of medications with adequate treatment of depressed elders. Finally, the lives of older adults in the United States over the past 20 years have been more healthy, happy, and economically viable than at any time during the twentieth century. Unfortunately, current government policies, especially the erosion of retirement plans, increasingly evasive universal health care, and the erosion of more meaningful and long-lasting social ties (295) may place older adults at much greater vulnerability over the next 20 years.

\section{ACKNOWLEDGMENT}

Address correspondence to Dan G. Blazer, Department of Psychiatry and Behavioral Sciences and Center for the Study of Aging, Box 3003, Duke University Medical Center, Durham, NC 27710. E-mail: blaze001@ mc.duke.edu

\section{REFERENCES}

1. Styron W. Darkness Visible: A Memoir of Madness. New York: Random House; 1990
2. Blazer D, Burchett B, Service C, George L. The association of age and depression among the elderly: an epidemiologic exploration. J Gerontol Med Sci. 1991;46:M210-M215.

3. Blazer D, Hughes D, George L. The epidemiology of depression in an elderly community population. Gerontologist 1987;27:281-287.

4. Berkman L, Berkman C, Kasl S, et al. Depressive symptoms in relation to physical health and functioning in the elderly. Am J Epidemiol. 1986; 124:372-388.

5. Doraiswamy P, Khan Z, Donahue R, Richard NE. The spectrum of quality-of-life impairments in recurrent geriatric depression. J Gerontol Med Sci. 2002;57A:M134-M137.

6. Blazer D. Depression in Late Life. New York: Springer; 2002.

7. Schneider L, Reynolds C, Lebowitz B, Friedhoff A. Diagnosis and Treatment of Depression in Late Life. Washington, DC: American Psychiatric Press; 1994.

8. Weissman M, Bruce M, Leaf P, Florio L, Holzer III C. Affective disorders. In: Regier DA, Robins LN, eds. Psychiatric Disorders in America. New York: The Free Press; 1991:53-80.

9. Blazer D, Williams C. The epidemiology of dysphoria and depression in an elderly population. Am J Psychiatr. 1980;137:439-444.

10. Beekman A, Deeg D, van Tilberg T, Smit J, Hooijer C, van Tilberg W. Major and minor depression in later life: a study of prevalence and risk factors. J Affect Disord. 1995;36:65-75.

11. Beekman A, Copeland J, Prince M. Review of community prevalence of depression in later life. Br J Psychiatr. 1999;174:307-311.

12. Steffens D, Skook I, Norton MC. Prevalence of depression and its treatment in an elderly population: the Cache County study. Arch Gen Psychiatr. 2000;57:601-607.

13. Beekman A, Geerlings S, Deeg D, et al. The natural history of late-life depression. Arch Gen Psychiatr. 2002;59:605-611.

14. Alexopoulos G, Meyers B, Young R, Mattis S, Kakuma T. The course of geriatric depression with "reversible dementia": a controlled study. Am J Psychiatr. 1993;150:1693-1699.

15. Schulz R, Drayer R, Rollman B. Depression as a risk factor for nonsuicide mortality in the elderly. Biol Psychiatr. 2002;52:205-225.

16. Alexopoulos G, Meyers B, Young R, Campbell S, Silbersweig D, Charlson M. 'Vascular depression' hypothesis. Arch Gen Psychiatr. 1997;54:915-922.

17. Kumar A, Zhisong J, Bilker W, Udupa J, Gottlieb G. Late-onset minor and major depression: early evidence for common neuroanatomical substrates detected by using MRI. Proc Nat Acad Sci. 1998;95:7654 7658.

18. Sheline Y, Mintun M, Moerlein S, Snyder A. Greater loss of 5-HT(2A) receptors in midlife than in late life. Am J Psychiatr. 2002;159:430435.

19. Salzman C, Wong E, Wright B. Drug and ECT treatment of depression in the elderly, 1996-2001: a literature review. Biol Psychiatr. 2002; 52:265-284.

20. Arean P, Cook B. Psychotherapy and combined psychotherapy/ pharmacotherapy for late life depression. Biol Psychiatr. 2002;52: 293-303.

21. Engel G. The clinical application of the biopsychosocial model. Am J Psychiatr. 1980;137:535-544.

22. Blazer D. Depression in the elderly. N Engl J Med. 1989;320:164 166.

23. Blazer D, Landerman L, Hays J, Simonsick E, Saunders W. Symptoms of depression among community-dwelling elderly AfricanAmerican and White older adults. Psychol Med. 1998;28:1311-1320.

24. Ross C, Mirowsky J. Components of depressed mood in married men and women: The Center for Epidemiologic Studies, Depression Scale. Am J Epidemiol. 1984;122:997-1004.

25. APA. DSM-IV: Diagnostic and Statistical Manual of Mental Disorders. Washington, DC: American Psychological Association; 1994.

26. Blazer D, Bachar J, Hughes D. Major depression with melancholia: a comparison of middle-aged and elderly adults. J Am Geriatr Soc. 1987;35:927-932.

27. Parker G, Roy K, Hadzi-Pavlovic D, Wilhelm K, Mitchell P. The differential impact of age on the phenomenology of melancholia. Psychol Med. 2001;31:1231-1236.

28. Parker G. Classifying depression: should paradigms lost be regained? Am J Psychiatr. 2000;157:1195-1203.

29. Radloff L. The CES-D Scale: a self-report depression scale for research in the general population. Appl Psychol Meas. 1977;1:385-401. 
30. Snaith R. The concepts of mild depression. Br J Psychiatr. 1987;150: 387-393.

31. Hybels C, Blazer D, Pieper C. Toward a threshold for subthreshold depression: an analysis of correlates of depression by severity of symptoms using data from an elderly community survey. Gerontologist. 2001;41:357-365.

32. Gallo J, Rabins P, Lyketsos C. Depression without sadness: functional outcomes of nondysphoric depression in later life. J Am Geriatr Soc. 1997;45:570-578.

33. Gallo J, Rabins P, Anthony J. Sadness in older persons: 13-year follow-up of a community sample in Baltimore, Maryland. Psychol Med. 1999;29:341-350.

34. Adams K. Depressive symptoms, depletion, or developmental change? Withdrawal, apathy, or lack of vigor in the Geriatric Depression Scale. Gerontologist. 2001;41:768-777.

35. Newman J. Aging and depression. Psychol Aging. 1989;4:150-165.

36. Newman J, Engel R, Jensen J. Age differences in depressive symptom experiences. J Gerontol. 1991;46:224-235.

37. Devenand D, Noble M, Singer T, et al. Is dysthymia a different disorder in the elderly? Am J Psychiatr. 1994;151:1592-1599.

38. Blazer D. Dysthymia in community and clinical samples of older adults. Am J Psychiatr. 1994;151:1567-1569.

39. Horowitz A. Creating Mental Illness. Chicago: University of Chicago Press; 2002.

40. Parker G, Hadzi-Pavlovic D. Melancholia: A Disorder of Movement and Mood. New York: Cambridge University Press; 1996.

41. Blazer D. Psychiatry and the oldest old. Am J Psychiatr. 2000;157: 1915-1924.

42. Sullivan M, LaCroix A, Baum C. Functional status in coronary artery disease: a one year prospective study of the role of anxiety and depression. Am J Med. 1997;103:348-356.

43. Blazer D, Moody-Ayers S, Craft-Morgan J, Burchett B. Depression in diabetes and obesity: racial/ethnic/gender issues in older adults. J Psychosom Res. 2002;52:1-4.

44. Magaziner J, Simonsick E, Kashner M. Predictors of functional recovery in the years following hospital discharge for hip fracture. J Gerontol Med Sci. 1990;45:M110-M107.

45. Robinson R, Price T. Post-stroke depressive disorders: a follow-up study of 103 patients. Stroke. 1982;13:635-641.

46. Black S, Goodwin J, Markides K. The association between chronic diseases and depressive symptomology in older Mexican Americans. J Gerontol Med Sci. 1998;53A:M118-M194.

47. Krishnan K, Hays J, Blazer D. MRI-defined vascular depression. Am J Psychiatr. 1997;154:497-501.

48. Reifler B, Larson E, Henley R. Coexistence of cognitive impairment and depression in geriatric outpatients. Am J Psychiatr. 1982;139:623-626.

49. Patterson M, Schnell A, Martin R, Mendez M, Smyth K. Assessment of behavioral and affective symptoms in Alzheimer's disease. $J$ Geriatr Psychiatr Neurol. 1990;3:21-30.

50. Weiner M, Edland S, Luszczynska H. Prevalence and incidence of major depression in Alzheimer's Disease. Am J Psychiatr. 1994;151: 1006-1009.

51. Rubin E, Veiel L, Kinscherf D, Morris J, Storandt M. Clinically significant depressive symptoms and very mild to mild dementia of the Alzheimer type. Int J Geriatr Psychiatr. 2001;16:694-701.

52. Brodarty H, Luscombe G, Parker G, et al. Early and late onset depression in old age: different aetologies, same phenomenology. $J$ Affect Disord. 2001;66:225-236.

53. Salloway S, Malloy P, Kohn R, et al. MRI and neuropsychological differences in early- and late-life-onset geriatric depression. Neurology. 1996;46:1567-1574.

54. Beats B, Sahakian B, Levy R. Cognitive performance in tests sensitive to frontal lobe dysfunction in the elderly depressed. Psychol Med. 1996;26:591-603.

55. Alexopoulos G, Vrontou C, Kakuma T, et al. Disability in geriatric depression. Am J Psychiatr. 1996;153:877-885.

56. Lockwood K, Alexopoulos G, vanGorp W. Executive dysfunction in geriatric depression. Am J Psychiatr. 2002;159:1119-1126.

57. Hickie I, Scott E, Naismith S, et al. Late-onset depression: genetic, vascular and clinical contributions. Psychol Med. 2001;31:1403-1412.

58. Meyers B. Geriatric delusional depression. Clin Geriatr Med. 1992;8: 299-308.
59. Kivela S, Pahkala K, Laippala P. Prevalence of depression in an elderly Finnish population. Acta Psychiatr Scand. 1988;78:401-413.

60. Olin J, Schneider L, Katz I, et al. Provisional diagnostic criteria for depression of Alzheimer Disease. Am J Geriatr Psychiatr. 2002;10: $125-128$.

61. Charles S, Reynolds C, Gatz M. Age-related differences and changes in positive and negative affect over 23 years. J Personal Social Psychol. 2001;80:136-151.

62. Murrell S, Himmelfarb S, Wright K. Prevalence of depression and its correlates in older adults. Am J Epidemiol. 1983;117:173-185.

63. Mirowsky J, Reynolds J. Age, depression, and attrition in the National Survey of Families and Households. Sociolog Methods Res. 2000;28: 476-504.

64. Schieman S, van Gundy K, Taylor J. The relationship between age and depressive symptoms: a test of competing explanatory and suppression influences. J Aging Health. 2002;14:260-285.

65. Blazer D, Swartz M, Woodbury M, Manton K, Hughes D, George L. Depressive symptoms and depressive diagnoses in a community population. Arch Gen Psychiatr. 1988;45:1078-1084.

66. Gonzalez H, Haan M, Hinton L. Acculturation and the prevalence of depression in older Mexican Americans: baseline results from the Sacramento Area Latino Study on Aging. J Am Geriatr Soc. 2001; 49:948-953.

67. Teresi J, Abrams R, Holmes D, Ramirez M, Shapiro C, Eimicke J. Influence of cognitive impairment, illness, gender, and AfricanAmerican status on psychiatric ratings and staff recognition of depression. Am J Geriatr Psychiatr. 2002;10:506-514.

68. Blazer D, Hybels C, Simonsick E, Hanlon J. Marked differences in antidepressant use by race in an elderly community sample: 19861996. Am J Psychiatr. 2000;157:1089-1094.

69. White L, Blazer D, Fillenbaum G. Related health problems. In: CornoniHuntley J, Blazer D, Lafferty M, Everett D, Brock D, Farmer M, eds. Established Populations for Epidemiologic Studies of the Elderly. Bethesda, MD: National Institute on Aging; 1990:70-85.

70. Meller I, Fichter M, Schroppel H. Incidence of depression in octo- and nonagenerarians: results of an epidemiological follow-up community study. Europ Arch Psychiatr Clin Neurosci. 1996;246:93-99.

71. Robins L, Helzer J, Croughan J. Diagnostic Interview Schedule: its history, characteristics and validity. Arch Gen Psychiatr. 1981;38: 381-389.

72. Copeland J, Dewey M, Wood N, Searle R, Davidson I, McWilliam C. Range of mental illness among the elderly in the community: prevalence in the Liverpool area using the GMS-AGECAT package. Br J Psychiatr. 1987;150:815-823.

73. Palsson S, Ostling S, Skoog I. The incidence of first-onset depression in a population followed from the age of 70 to 85. Psychol Med. 2001; 31:1159-1168.

74. Eaton W, Kramer M, Anthony J, Dryman A, Shapiro S, Locke B. The incidence of specific DIS/DSM-III mental disorders: data from the NIMH epidemiologic catchment area program. Acta Psychiatr Scand. 1989;79:109-125.

75. Forsell V, Winblad B. Incidence of major depression in a very elderly population. Intl J Geriatr Psychiatr. 1999;14:368-372.

76. Koenig H, Meador K, Cohen H, Blazer DG. Depression in elderly hospitalized patients with medical illness. Arch Intern Med. 1988;148: 1929-1936.

77. Lyness J, Caine E, King D, Conwell Y, Duberstein P, Cox C. Depressive disorders and symptoms in older primary care patients. $A m$ J Geriatr Psychiatr. 2002;10:275-282.

78. Oxman T, Barrett J, Barrett J, Gerber P. Symptomology of late-life minor depression among primary care patients. Psychosomatics. 1990; 31:174-180.

79. Schulberg H, Mulsant B, Schulz R, Rollman B, Houck P, Reynolds C. Characteristics and course of major depression in older primary care patients. Intl J Psychiatr Med. 1998;28:421-436.

80. Parmelee P, Katz I, Lawton M. Depression among institutionalized aged: assessment and prevalence estimation. J Gerontol Med Sci. 1989;44:M22-M29.

81. Payne J, Sheppard J, Steinberg M, et al. Incidence, prevalence and outcomes of depression in residents of a long-term care facility with dementia. Intl J Geriatr Psychiatr. 2002;17:247-253. 
82. Teresi J, Abrams R, Holmes D, Ramirez M, Eimicke J. Prevalence of depression and depression recognition in nursing homes. Soc Psychiatr Psychiatr Epidemiol. 2001;36:613-629.

83. Brown M, Lapane K, Luisi A. The management of depression in older nursing home patients. $J$ Am Geriatr Soc. 2002;50:69-76.

84. Yesavage J, Brink T, Rose T. Development and validation of a geriatric depression screening scale: a preliminary report. J Psychiatr Res. 1983;17:37-49.

85. Soon J, Levine M. Screening for depression in patients in long-term care facilities: a randomized controlled trial of physician response. J Am Geriatr Soc. 2002;50:1092-1099.

86. Post F. The Significance of Affective Symptoms at Old Age. London: Oxford University Press; 1962.

87. Murphy E. The prognosis of depression in old age. Br J Psychiatr. 1983;142:111-119.

88. Baldwin R, Jolley D. The prognosis of depression in old age. $\mathrm{Br} J$ Psychiatr. 1986;149:574-583.

89. Alexopoulos G, Meyers B, Young R, et al. Recovery in geriatric depression. Arch Gen Psychiatr. 1996;53:305-312.

90. Reynolds C, Frank E, Pereil J. Combined pharmacotherapy and psychotherapy in the acute and continuation treatment of elderly patients with recurrent major depression: a preliminary report. Am J Psychiatr. 1992;149:1687-1692.

91. Blazer D, Hughes D, George L. Age and impaired subjective support: predictors of depressive symptoms at one-year follow-up. J Nervous Mental Dis. 1992;180:172-178.

92. Brodaty J, Luscombe G, Peisah C, Anstey K, Andrews G. A 25-year longitudinal, comparison study of the outcome of depression. Psychol Med. 2001;31:1347-1359.

93. Keller M, Shapiro R, Lavori P, Wolfe N. Recovery in major depressive disorder: analyses with the life table. Arch Gen Psychiatr. 1982; 39:905-910.

94. Keller M, Shapiro R, Lavori P, Wolfe N. Relapse in major depressive disorder: analysis with the life table. Arch Gen Psychiatr. 1982;39: 911-915.

95. Bosworth H, McQuoid D, George L, Steffens D. Time-to-remission from geriatric depression. Am J Geriatr Psychiatr. 2002;10:551-559.

96. Morley J, Kraenzle D. Causes of weight loss in a community nursing home. J Am Geriatr Soc. 1994;42:583-585.

97. Frasure-Smith N, Lesperance F, Talajic M. Depression following myocardial infarction. Impact on 6-month survival. JAMA. 1993;270: $1819-1825$.

98. Romanelli J, Fauerbach J, Buch D, Ziegelstein R. The significance of depression in older patients after myocardial infarction. J Am Geriatr Soc. 2002;50:817-822.

99. Williams S, Kasl S, Heiat A, Abramson J, Krumholz H, Vaccarino V. Depression and risk of heart failure among the elderly: a prospective community-based study. Psychosomatic Med. 2002;64:6-12.

100. McGuire L, Kiecolt-Glaser J, Glaser R. Depressive symptoms and lymphocyte proliferation in older adults. J Abnorm Psychol. 2002;111: 192-197.

101. Robbins J, Hirsch C, Whitmer R, Cauley J, Harris T. The association of bone mineral density and depression in an older population. $J \mathrm{Am}$ Geriatr Soc. 2001;49:732-736.

102. Lyles K. Osteoporosis and depression: shedding more light upon a complex relationship. J Am Geriatr Soc. 2001;49:827-828.

103. Han B. Depressive symptoms and self-rated health in communitydwelling older adults: a longitudinal study. J Am Geriatr Soc. 2002; 50:1549-1556.

104. Whyte E, Pollock BG, Wagner W, et al. Influence of serotonin transporter-linked region polymorphism on platelet activation in geriatric depression. Am J Psychiatr. 2001;158:2074-2076.

105. Galanos A, Pieper C, Cornoni-Huntley J. Nutrition and function: is there a relationship between body mass index and the functional capabilities of community-dwelling elderly? J Am Geriatr Soc. 1994; 42:368-373.

106. Fried L, Walston J. Frailty and failure to thrive. In: Hazzard W, Blass J, Ettinger W, Halter J, Ouslander J, eds. Principles of Geriatric Medicine and Gerontology. New York: McGraw-Hill; 1999:1387-1402.

107. Michelson D, Stratakis C, Hill L. Bone mineral density in women with depression. N Engl J Med. 1996;335:1176-1181.
108. Schweiger U, Deuschle M, Korner A. Low lumbar bone mineral density in patients with major depression. Am J Psychiatr. 1994;151: 1691-1695.

109. Hays J, Saunders W, Flint E, Blazer D. Social support and depression as risk factors for loss of physical function in late life. Aging Mental Health. 1997;1:209-220.

110. Bruce M. Depression and disability in late life: directions for future research. Am J Geriatr Psychiatr. 2001;9:102-112.

111. Bruce M, Leaf P. Psychiatric disorders and 15-month mortality in a community sample of older adults. Am J Publ Health. 1989;79:727730.

112. Zeiss A, Lewinsohn P, Rohde P. Relationship of physical disease and functional impairment to depression in older people. Psychol Aging. 1996;11:572-581.

113. Penninx B, Leveille S, Ferrucci L, van Eijk J, Guralnik J. Exploring the effect of depression on physical disability: longitudinal evidence from the Established Populations for Epidemiologic Studies of the Elderly. Am J Publ Health. 1999;89:1346-1352.

114. Kennedy G, Kelman H, Thomas C. The emergence of depressive symptoms in late life: the importance of declining health and increasing disability. J Commun Health. 1990;15:93-104.

115. Roberts R, Kaplan G, Shema S. Does growing old increase the risk for depression? Am J Psychiatr. 1997;154:1384-1390.

116. Blazer D. Impact of late-life depression on the social network. Am J Psychiatr. 1983;140:162-166.

117. Lenze E, Rogers J, Martire L, et al. The association of late-life depression and anxiety with physical disability. Am J Geriatr Psychiatr. 2001;9:113-135.

118. Pohjasvaara T, Vataja R, Leppavuori A, Kaste M, Erkinjuntti T. Depression is an independent predictor of poor long-term functional outcome post-stroke. Europ J Neurol. 2001;8:315-319.

119. Sinclair P, Lyness J, King D, Cox C, Caine E. Depression and selfreported functional status in older primary care patients. Am J Psychiatr. 2001;158:416-419.

120. Hays J, Steffens D, Flint E, Bosworth H, George L. Does social support buffer functional decline in elderly patients with unipolar depression? Am J Psychiatr. 2001;158:1850-1855.

121. Li Y, Meyer J, Thornby J. Longitudinal follow-up of depressive symptoms among normal versus cognitively impaired elderly. Intl J Geriatr Psychiatr. 2001;16:718-727.

122. Lyketsos C, Baker L, Warren A, Steele C, Brandt J, Steinberg M. Major and minor depression in Alzheimer's disease: prevalence and impact. J Neuropsychiatr Clin Neurosci. 1997;9:556-561.

123. Lyketsos C, Steele C, Galik E, et al. Physical aggression in dementia patients and its relationship to depression. Am J Psychiatr. 1999;156: 66-71.

124. Gonzales-Salvador T, Aragano C, Lyketsos C, Barba A. The stress and psychological morbidity of the Alzheimer patient caregiver. Intl J Geriatr Psychiatr. 1999;14:701-710.

125. Geerlings S, Beekman A, Beeg D, Twisk J, van Tilburg W. Duration and severity of depression predict mortality in older adults in the community. Psychol Med. 2002;32:609-618.

126. Henderson A, Korten A, Jacomb P, et al. The course of depression in the elderly: a longitudinal community based study in Australia. Psychol Med. 1997;27:119-129.

127. Takeida K, Nishi M, Miyake H. Zung's depression scale as a predictor of death in elderly people: a cohort study in Hokkaido, Japan. $J$ Epidemiol. 1999;9:240-244.

128. Penninx B, Geerlings S, Deeg D, van Eijk J, van Tilling W, Beekman A. Minor and major depression and the risk of death in older persons. Arch Gen Psychiatr. 2001;56:889-895.

129. Schulz R, Beach S, Ives D. Association between depression and mortality in older adults: The Cardiovascular Health Study. Arch Intl Med. 2000;160:1761-1768.

130. Fredman L, Schoenbach V, Kaplan B, Blazer D, James S. The association between depressive symptoms and mortality among older participants in the Epidemiologic Catchment Area-Piedmont Health Survey. J Gerontol Soc Sci. 1989;44:S149-S156.

131. Thomas C, Kelman H, Kennedy G. Depressive symptoms and mortality in elderly persons. J Gerontol. 1992;24:580-587.

132. Blazer D, Hybels C, Pieper C. The association of depression and mortality in elderly persons: a case for multiple independent pathways. J Gerontol Med Sci. 2001;56A:M505-M509. 
133. Takeshita J, Masaki K, Ahmed I, et al. Are depressive symptoms a risk factor for mortality in elderly Japanese American men?: The Honolulu Asia Aging Study. Am J Psychiatr. 2002;159:1127-1132.

134. Whooley M, Browner W. Association between depressive symptoms and mortality in older women. Study of Osteoporotic Fractures Research Group. Arch Intern Med. 1999;158:2129-2135.

135. Saz P, Dewey M. Depression, depressive symptoms and mortality in persons aged 65 and over living in the community: a systematic review of the literature. Intl J Geriatr Psychiatr. 2001;16:622-630.

136. Hybels C, Pieper C, Blazer D. Gender differences in the relationship between subthreshold depression and mortality in a community sample of older adults. Am J Geriatr Psychiatr. 2002;10:283-291.

137. NCHS. Death Rates for 72 Selected Causes by 5-year Age Groups, Race, and Sex: United States, 1979-1998. Washington, DC: National Center for Health Statistics; 2001.

138. Conwell Y, Duberstein P, Caine E. Risk factors for suicide in later life. Biol Psychiatr. 2002;52:193-204.

139. Murphy GE, Wetzel RD. Suicide risk by birth cohort in the United States, 1949 to 1974. Arch Gen Psychiatr. 1980;37:519-523.

140. Blazer D, Bachar J, Manton K. Suicide in late life: review and commentary. J Am Geriatr Soc. 1986;34:519-526.

141. Raern M, Reneson B, Allebeck P, et al. Mental disorder in elderly suicides: a case-control study. Am J Psychiatr. 2002;159:450-455.

142. Conwell Y, Lyness J, Duberstein P, Cox C, Seidlitz L, DiGiorgio A. Completed suicide among older patients in primary care practices: a controlled study. J Am Geriatr Soc. 2000;48:23-29.

143. Turvey C, Conwell Y, Jones M, et al. Risk factors for late-life suicide: a prospective, community-based study. Am J Geriatr Psychiatr. 2002; 10:398-406.

144. De Leo D, Padoani W, Scocco P, et al. Attempted and completed suicide in older subjects: results from the WHO/EURO Multicentre study of suicidal behaviour. Intl J Geriatr Psychiatr. 2001;16:300-310.

145. Parkin D, Stengel E. Incidence of suicidal attempts in an urban community. Br Med J. 1965;2:133-138.

146. Huang B, Cornoni-Huntley J, Hays J, Huntley R, Galanos A, Blazer D. Impact of depressive symptoms on hospitalization risk in communitydwelling older persons. J Am Geriatr Soc. 2000;48:1279-1284.

147. Unutzer J, Patrick D, Simon G, et al. Depressive symptoms and the cost of health services in HMO patients $65+$ years and older. JAMA. 1997;277:1618-1623.

148. Luber M, Meyers B, Williams-Russo P, et al. Depression and service utilization in elderly primary care patients. Am J Geriatr Psychiatr. 2001;9:169-176.

149. Fischer L, Wei F, Rolnick S, et al. Geriatric depression, antidepressant treatment, and healthcare utilization in a health maintenance organization. J Am Geriatr Soc. 2002;50:307-312.

150. Starkstein S, Preziosi T, Bolduck P, Robinson R. Depression in Parkinson's disease. J Nervous Mental Disord. 1990;178:27-31.

151. Parmelee P, Katz I, Lawton M. The relation of pain to depression among institutionalized aged. J Gerontol. 1991;46:15-21.

152. Endberg S, Sereika S, Weber E, Engberg R, McDowell B, Reynolds C. Prevalence and recognition of depressive symptoms among homebound older adults with urinary incontinence. J Geriatr Psychiatr Neurol. 2001;14:130-139.

153. Gilman S, Abraham H. A longitudinal study of the order of onset of alcohol dependence and major depression. Drug Alcohol Depend. 2001;63:277-286.

154. Jorm A. Association of hypotension with positive and negative affect and depressive symptoms in the elderly. Br J Psychiatr. 2001;178:553555.

155. Holsinger T, Steffens D, Phillips C, et al. Head injury in early adulthood and the lifetime risk of depression. Arch Gen Psychiatr. 2002; 59:17-22.

156. Barondes S. Mood Genes: Hunting for Origins of Mania and Depression. New York: WH Freeman; 1998.

157. Gatz M, Pedersen N, Plomin R, Nesselroade J, McClearn G. Importance of shared genes and shared environments for symptoms of depression in older adults. J Abnorm Psychol. 1992;101:701-708.

158. Hopkinson G. A genetic study of affective illness in patients over 50. Br J Psychiatr. 1964;110:244-252.

159. Blazer D, Burchette B, Fillenbaum G. APOE E4 and low cholesterol as risks for depression in a biracial elderly community sample. Am $J$ Geriatr Psychiatr. 2002;10:515-520.
160. Nebes R, Vora I, Melzer C, et al. Relationship of deep white matter hyperintensities and apolipoprotein E genotype to depressive symptoms in older adults without clinical depression. Am J Psychiatr. 2001;158:878-884.

161. Desmond D, Moroney J, Lynch T, Chan S, Chin S, Mohr J. The natural history of CADASIL: a pooled analysis of previously published cases. Stroke. 1999;30:1230-1233.

162. Krishnan K. Biological risk factors in late life depression. Biol Psychiatr. 2002;52:185-192.

163. Krishnan K, Goli V, Ellinwood E, Blazer D, Nemeroff C. Leukoencephalopathy in patients diagnosed as major depressive. Biol Psychiatr. 1988;23:519-522.

164. Coffey C, Figiel G, Djang W. Subcortical hyperintensity on magnetic resonance imaging: a comparison of normal and depressed elderly subjects. Am J Psychiatr. 1990;147:187-189.

165. Kumar A, Mintz J, Bilker W, Gottlieb G. Autonomous neurobiological pathways to late-life depressive disorders: clinical and pathophysiological implications. Neuropsychopharmacology. 2002;26: 229-236.

166. Kumar A, Thomas A, Lavretsky H, et al. Frontal white matter biochemical abnormalities in late-life major depression detected with proton magnetic resonance spectroscopy. Am J Psychiatr. 2002;159: 630-636.

167. George M, Ketter T, Post R. Prefrontal cortex dysfunction in clinical depression. Depression. 1994;2:59-72.

168. Krishnan K, McDonald W, Doraiswamy P, et al. Neuroanatomical substrates of depression in the elderly. Europ Arch Psychiatr Clin Neurosci. 1993;243:41-46.

169. Krishnan K, McDonald W, Escalona P, et al. Magnetic imaging of the caudate nuclei in depression: preliminary observation. Arch Gen Psychiatr. 1992;49:553-557.

170. Husain M, McDonald W, Doraiswamy P, et al. A magnetic resonance imaging study of putamen nuclei in major depression. Psychiatr Res. 1991;40:95-99.

171. Lai T, Payne M, Byrum C, Steffens D, Krishnan K. Reduction of orbital fronal cortex volume in geriatric depression. Biol Psychiatr. 2000;48:971-975.

172. Steffens D, Payne M, Greenberg D, et al. Hippocampal volume and incident dementia in geriatric depression. Am J Geriatr Psychiatr. 2002; 10:62-71

173. Nemeroff C, Knight D, Krishnan K, Slotkin T, Bissette G, Blazer D. Marked reduction in the number of platelet tritiated imipramine binding sites in geriatric depression. Arch Gen Psychiatr. 1988;45:919-923.

174. Tsukada H, Kakiuchi T, Nishiyama S, Ohba H, Harada N. Effects of aging on 5-HT(1A) receptors and their functional response to 5-HT(1A) agonist in the living brain: PET study with [carbonyl-(11)C]WAY100635 in conscious monkeys. Synapse. 2001;42:242-251.

175. Davis K, David B, Mathe A, Mohs R, Rothpearl A. Age and the dexamethasone supression test in depression. Am J Psychiatr. 1984;141: 872-874.

176. Arborelius L, Owens M, Plotsky P, Nemeroff C. The role of corticotropin-releasing factor in depression and anxiety disorders. J Endocrinol. 1999;160:1-12.

177. Luisi S, Tonetti A, Bernardi F, et al. Effect of acute corticotropin releasing factor on pituitary-adrenocortical responsiveness in elderly women and men. $J$ Endocrinol Invest. 1998;21:449-453.

178. Yaffe K, Ettinger B, Pressman A. Neuropsychiatric function and dehydroepiandrosterone sulfate in elderly women: a prospective study. Biol Psychiatr. 1998;43:694-700.

179. Seidman S, Araujo A, Roose S, et al. Low testosterone levels in elderly men with dysthymic disorder. Am J Psychiatr. 2002;159:456-459.

180. Seidman S, Spatz E, Rizzo C, Roose S. Testosterone replacement therapy for hypogonadal men with major depresive disorder: a randomized, placebo-controlled clinical trial. J Clin Psychiatr. 2001;62: 406-412.

181. Schwartz S, Feller A, Perlmuter L. Postprandial systolic blood pressure and subsyndromal depression. Exp Aging Res. 2001;27:309-318.

182. Sherwin B, Gelfand M. Sex steroids and affect in the surgical menopause: a double-blind, cross-over study. Psychoneuroendocrinology. 1985; 10:325-335.

183. Seligman MEP. Learned helplessness. Annu Rev Med. 1972;23:407.

184. Seligman M, Maier S. Failure to escape traumatic shock. $J$ Exp Psychol. 1967;74:1-15. 
185. Kraaij V, de Wilde E. Negative life events and depressive symptoms in the elderly: a life span perspective. Aging Mental Health. 2001;5: 84-91.

186. Kraaij V, Arensman E, Spinhoven P. Negative life events and depression in elderly persons: a meta-analysis. J Gerontol Psychol Soc Sci. 2002:57B:P87-P94.

187. Brilman E, Ormel J. Life events, difficulties and onset of depressive episodes in later life. Psychol Med. 2001;31:859-869.

188. Cath S. Discussion notes. In: Berezin N, Cath S, eds. Geriatric Psychiatry. New York: International Universities Press; 1965.

189. Baltes P, Baltes M. Successful Aging: Perspectives from the Behavioral Sciences. Cambridge: Cambridge University Press; 1990.

190. Beck AT. Depression. New York: Harper \& Row; 1967.

191. Devenand D, Kim M, Paykina N, Sackeim H. Adverse life events in elderly patients with major depression or dysthymia and in healthycontrol subjects. Am J Geriatr Psychiatr. 2002;10:265-274.

192. Beck A. Cognitive model of depression. J Cog Psychother. 1987;1: 2-27.

193. Mazure C, Maciejewski P, Jacobs S, Bruce M. Stressful life events interacting with cognitive/personality styles to predict late-onset major depression. Am J Geriatr Psychiatr. 2002;10:297-304.

194. Chi I, Chou K. Social support and depression among elderly Chinese people in Hong Kong. Intl J Aging Human Devel. 2001;52:231-252.

195. George L, Blazer D, Hughes D, Fowler N. Social support and the outcome of major depression. Br J Psychiatr. 1989;154:478-485.

196. Livingston G, Manela M, Katona C. Depression and other psychiatric morbidity in carers of elderly people living at home. Br Med J. 1996; 312:153-156.

197. Clipp E, George L. Psychotropic drug use among caregivers of patients with dementia. J Am Geriatr Soc. 1990;38:227-235.

198. Beeson R, Horton-Deutsch S, Farran C, Neurndorfer M. Loneliness and depression in caregivers of persons with Alzheimer's disease or related disorders. Issues Mental Health Nurs. 2000;21:779-906.

199. Lewinsohn P, Rohde P, Seeley J, Fischer S. Age and depression: unique and shared effects. Psychol Aging. 1989;6:247-260.

200. Cumming E, Henry W. Growing Old: The Process of Disengagement. New York: Basic Books; 1961.

201. Fonda S, Wallace R, Herzog A. Changes in driving patterns and worsening depressive symptoms among older adults. J Gerontol Psychol Soc Sci. 2001;56B:S343-S351.

202. Braam A, van den Eeden P, Prince M, et al. Religion as a crosscultural determinant of depression in elderly Europeans: results from the EURODEP collaboration. Psychol Med. 2001;31:803-814.

203. Koenig H, Cohen H, Blazer D, et al. Religious coping and depression in elderly hospitalized medically ill men. Am J Psychiatr. 1992;149: 1693-1700.

204. Koenig H, Cohen H, Blazer D, Kudler H, Krishnan K, Sibert T. Cognitive symptoms of depression and religious coping in elderly medical patients. Psychosomatics. 1995;36:369-375.

205. Koenig H, Meador K, Cohen H, Blazer D. Screening for depression in hospitalized elderly medical patients: taking a closer look. $J$ Am Geriatr Soc. 1992;40:1013-1017.

206. Callahan C, Hendrie H, Nienaber N, Tierney W. Suicidal ideation among older primary care patients. J Am Geriatr Soc. 1996;44:12051209.

207. Callahan C, Nienaber N, Hendrie H, Tierney W. Depression of elderly outpatients: primary care physicians attitudes and practice patterns. J Gen Intern Med. 1992;7:26-31.

208. Callahan C, Hendrie H, Tierney W. The recognition and treatment of late-life depression: a view from primary care. Intl J Psychiatr Med. 1996;26:173-175

209. Callahan C, Hendrie H, Dittus R, Brater D, Hui S, Tierney W. Improving treatment of late life depression in primary care: a randomized clinical trial. J Am Geriatr Soc. 1994;42:839-846.

210. Folstein M, Folstein S, McHugh P. Mini-Mental State: a practical method for grading the cognitive state of patients for the clinician. J Psychiatr Res. 1975;12:189-198.

211. Schoenfeld D, Malmrose L, Blazer D, Gold D, Seeman T. Self-rated health and mortality in the high-functioning elderly-a closer look at healthy individuals: MacArthur Field Study of Successful Aging. J Gerontol Med Sci. 1994;49A:M109-M115.

212. Branch L, Meyers A. Assessing physical function in the elderly. Clin Geriatr Med. 1987:3:29-51.
213. Fillenbaum G. Multidimensional Functional Assessment of Older Adults: The Duke Older Americans Resources and Services Procedures. Hillsdale, NJ: Erlbaum; 1988.

214. Blazer D. Social support and mortality in an elderly community population. Am J Epidemiol. 1982;115:684-694.

215. Forlenza O, Junior A, Hirala E, Ferreira R. Antidepressant efficacy of sertraline and imipramine for the treatment of major depression in elderly outpatients. Sao Paolo Med J. 2000;118:99-104.

216. Kyle C, Petersen H, Overo K. Comparison of the tolerability and efficacy of citalopram and amitriptyline in elderly depressed patients treated in general practice. Depress Anxiety. 1998;8:147-153.

217. Mulsant B, Pollock B, Nebes R, et al. A twelve-week, double-blind, randomized comparison of nortriptyline and paroxetine in older depressed inpatients and outpatients. Am J Geriatr Psychiatr. 2001; 9:406-414.

218. Salloway S, Boyle P, Correia S, et al. The relationship of MRI subcortical hyperintensities to treatment response in a trial of sertraline in geriatric depressed outpatients. Am J Geriatr Psychiatr. 2002;10: 107-111.

219. Taragano F, Allegri R, Vicario A, Bagnatti P, Lyketsos C. A doubleblind, randomized clinical trial assessing the efficacy and safety of augmenting standard antidepressant therapy with nimodipine in the treatment of 'vascular depression.' Intl J Geriatr Psychiatr. 2001;16: 254-260.

220. Simpson S, Balwin R, Burns A, Jackson A. Regional cerebral volume measurements in late-life depression: relationship to clinical correlates, neuropschological impairment and response to treatment. Int J Geriatr Psychiatr. 2001;16:469-476.

221. Reifler B, Teri L, Raskind M, Veith R, Barnes R. Double-blind trial of imipramine in Alzheimer's disease patients with and without depression. Am J Psychiatr. 1989;146:45-49.

222. Lyketsos C, Sheppard J, Steele C, et al. A randomized placebocontrolled, double-blind, clinical trial of sertraline in the treatment of depression complicating Alzheimer disease: initial results from the Depression in Alzheimer Disease Study (DIADS). Am J Psychiatr. 2000; 157:1686-1689.

223. Nyth A, Gottfries C, Lyby K, et al. A controlled multicenter clinical study of citalopram and placebo in elderly depressed patients with and without concomitant dementia. Acta Psychiatr Scand. 1992;86: $138-145$.

224. Ackerman D, Greenland S, Bystritsky A, Small G. Side effects and time course of response in a placebo-controlled trial of fluoxetine for the treatment of geriatric depression. J Clin Psychopharmacol. 2000; 20:658-665.

225. Williams J, Barrett J, Oxman T, et al. Treatment of dysthymia and minor depression in primary care: a randomized controlled trial in older adults. JAMA. 2000;284:1519-1526.

226. Oxman T, Sungupta A. Treatment of minor depression. Am J Geriatr Psychiatr. 2002;10:256-264.

227. Group HDTS. Effect of hypericum perforatum (St. John's wort) in major depressive disorder: a randomized controlled trial. JAMA. 2002, 287:1807-1814.

228. Feighner J, Cohn J. Double-blind comparative trials of fluoxetine and doxepin in geriatric patients with major depression. J Clin Psychiatr. 1985;46:20-25.

229. Cohn C, Shrivastava R, Mendels J. Double-blind multicenter comparison of sertraline and amitriptyline in elderly depressed patients J Clin Psychiatr. 1990;51:28-33.

230. Katona C, Hunder B, Bray J. A double-blind comparison of paroxetine and imipramine in the treatment of depression with dementia. Intl J Geriatr Psychiatr. 1998;13:100-180.

231. Nyth A, Gottfried C, Lyby K. A controlled multicenter clinical study of citalipram and placebo in elderly depressed patients with and without concomitant dementia. Acta Psychiatr Scand. 1992;86:138-145.

232. Rahman M, Akhton M, Savia N, Kellet J, Ashford J. A double-blind, randomized comparison of fluvoxamine and dothiepin in the treatment of depression in the elderly. Br J Clin Pract. 1991;45:255-258.

233. Mahapatra S, Hackett D. A randomized, double-blind, paralled-group comparison of venlafaxine and dothiepin in geriatric patients with major depression. Intl J Clin Pract. 1997;51:209-213.

234. Hoyberg O, Maragakis B, Mullin J, et al. A double-blind multicentre comparison of mirtazapine and amitriptyline in elderly depressed patients. Acta Psychiatr Scand. 1996;93:184-190. 
235. Schatzberg A, Kremer C, Rodrigues H, Murphy G. Double-blind, randomized comparison of mirtazapine and paroxetine in elderly depressed patients. Am J Geriatr Psychiatr. 2002;10:541-550.

236. Branconnier R, Cole J, Ghazviain S, Spera K, Oxenkrug O. Clinical pharmacology of buproprion and imipramine in elderly depressives. J Clin Psychiatr. 1983;44:130-133.

237. Weihs K, Settle E, Batey S, Houser T, Donahue R, Ascher J. Buproprion sustained release versus paroxetine for the treatment of depression in the elderly. J Clin Psychiatr. 2001;61:196-202.

238. Baldwin D, Hawley C, Mellors K, Group C-S. A randomized, doubleblind controlled comparison of nefazodone and paroxetine in the treatment of depression: safety, tolerability and efficacy in continuation phase treatment. J Psychopharmacol. 2001;15:161-165.

239. Alexopoulos G, Katz I, Reynolds C, Carpenter D, Docherty J. The Expert Consensus Guideline Series: pharmacotherapy of depressive disorders in older patients. Postgrad Med. (special issue) 2001:1-86.

240. Schneider L, Small G, Clary C. Estrogen replacement therapy and antidepressant response to sertraline in older depressed women. Am $J$ Geriatr Psychiatr. 2001;9:393-399.

241. Morales A, Nolan J, Nelson J, Yen S. Effects of replacement dose of dehydroepiandrosterone in men and women of advancing age. $J$ Clin Endocrinol Metab. 1994;78:1360-1367.

242. Pollock B. Geriatric psychiatry: psychopharmacology: general principles. In: Sadock B, Sadock V, eds. Kaplan \& Sadock's Comprehensive Textbook of Psychiatry/VII. Baltimore, MD: Williams and Wilkins; 2000:3086-3090.

243. Greenblatt D, van Moltke L, Harmatz J, Shader R. Drug interactions with newer antidepressants: role of human cytochromes P450. J Clin Psychiatr. 1998;59(suppl 15):19-27.

244. Kirby D, Harigan S, Ames D. Hyponatraemia in elderly psychiatric patients treated with selective serotonin reuptake inhibitors and venlafaxine: a retrospective controlled study in an inpatient unit. Intl $J$ Geriatr Psychiatr. 2002;17:231-237.

245. Thapa P, Gideon P, Cost T, Milam A, Ray W. Antidepressants and the risk of falls among nursing home residents. N Engl J Med. 1998; 339:918-920.

246. Gillman P. The serotonin syndrome and its treatment. J Psychopharmacol. 1999;13:100-109.

247. de Abajo F, Rodriguez L, Montero D. Association between selective serotonin reuptake inhibitors and upper gastrointestinal bleeding: population based case-control study. Br Med J. 1999;319:1106-1109.

248. Flint A, Rifat S. The treatment of psychotic depression in later life: a comparison of pharmacotherapy and ECT. J Geriatr Psychiatr. 1998; 13:23-28.

249. Godber C, Rosenvinge H, Wilkinson D, Smithes J. Depression in old age: prognosis after ECT. Intl J Geriatr Psychiatr. 1987;2:19-24.

250. Benbow $\mathrm{S}$. The use of electroconvulsive therapy in old-age psychiatry. Intl J Geriatr Psychiatr. 1987;2:25-30.

251. Fraser R, Glass I. Unilateral and bilateral ECT in elderly patients. Acta Psychiatr Scand. 1980;62:13-31.

252. Benbow $\mathrm{S}$. The role of electroconvulsive therapy in the treatment of depressive illness in old age. Br J Psychiatr. 1989;155:147-152.

253. Cattan R, Barry P, Mead G, Reefe W, Gay A. Electroconvulsive therapy in octogenerians. J Am Geriatr Soc. 1990;38:753-758.

254. O'Conner M, Knapp R, Husain M, et al. The influence of age on the response of major depression to electroconvulsive therapy: a C.O.R.E. Report. Am J Geriatr Psychiatr. 2001;9:382-390.

255. McNamara B, Ray J, Arthurs O, Boniface S. Transcranial magnetic stimulation for depression and other psychiatric disorders. Psychol Med. 2001;31:1141-1146.

256. Dannon P, Dolberg O, Schreiber S, Grunhaus L. Three and six-month outcome following courses of either ECT or rTMS in a population of severely depressed individuals_preliminary report. Biol Psychiatr. 2002;51:687-690.

257. Moser D, Jorge R, Manes F, Paradiso S, Benjamin M, Robinson R. Improved exective functioning following repetitive transcranial magnetic stimulation. Neurology. 2002;58:1288-1290.

258. Camacho T, Roberts R, Lazarus N, Kaplan G, Cohen R. Physical activity and depression: evidence from the Alameda County Study. Am J Epidemiol. 1991;134:220-231.

259. Blumenthal J, Babyak M, Moore K, et al. Effects of exercise training on older patients with major depression. Arch Intern Med. 1999;159: 2349-2356.
260. Singh N, Clements K, Kingh M. The efficacy of exercise as a longterm antidepressant in elderly subjects: a randomized controlled trial. J Gerontol Med Sci. 2001;56A:M497-M504.

261. Sumaya I, Rienzi B, Beegan J, Moss D. Bright light treatment decreases depression in institutionalized older adults: a placebocontrolled crossover study. J Gerontol Med Sci. 2001;56A:M356M360.

262. Walker D, Clarke M. Cognitive behavioral psychotherapy: a comparison between younger and older adults in two inner city mental health teams. Aging Mental Health 2001;5:197-199.

263. Alvidrez J, Arean P. Physician willingness to refer older depressed patients for psychotherapy. Intl J Psychiatr Med. 2002;32:21-35.

264. Landreville P, Landry J, Baillargeon L, Guerette A, Matteau E. Older adults' acceptance of psychological and pharmacological treatments for depression. J Gerontol Psychol Sci. 2001;56B:P285-P291.

265. Thompson L, Gallagher D, Breckenridge J. Comparative effectiveness of psychotherapies for depressed elders. J Consult Clin Psychol. 1987; 55:385-390.

266. Karel M, Hinrichsen G. Treatment of depression in late life: psychotherapeutic interventions. Clin Psychol Rev. 2000;20:707-729.

267. Lynch T, Aspnes A. Individual and group psychotherapy. In: Blazer D, Steffens D, Busse E, eds. American Psychiatric Press Textbook of Geriatric Psychiatry. Washington, DC: American Psychiatric Press. In Press.

268. Teasdale J, Moore R, Hayhurst H. Metacognitive awareness and prevention of relapse in depression: empirical evidence. J Consult Clin Psychol. 2002;70:275-287.

269. Thompson L, Coon D, Gallagher-Thompson D. Comparision of desipramine and cognitive/behavioral therapy in the treatment of elderly outpatients with mild-to-moderate depression. Am J Geriatr Psychiatr. 2001;9:225-240.

270. Frank E, Frank N, Cornes C. Interpersonal psychotherapy in the treatment of late life depression. In: Klerman G, Weissman M, eds. New Applications of Interpersonal Psychotherapy. Washington, DC: American Psychiatric Press; 1993.

271. Frank E, Spanier C. Interpersonal psychotherapy for depression: overview, clinical efficacy, and future directions. Clin Psychol Sci Pract. 1995;2:349-365.

272. Reynolds C, Frank E, Perel J, et al. Nortriptyline and interpersonal psychotherapy as maintenance therapies for recurrent major depression: a randomized controlled trial in patients older than 59 years. JAMA. 1999;281:39-45.

273. Reynolds C, Frank E, Dew M, et al. Treatment of 70(+)-year olds with recurrent major depression. Excellent short-term but brittle longterm response. Am J Geriatr Psychiatr. 1999;7:64-69.

274. Myers W. Dynamic Therapy of the Older Patient. New York: Aronson; 1984

275. Gallagher D, Thompson L. Treatment of major depressive disorder in older outpatients with brief psychotherapies. Psychother Theory Res Prac. 1982;19:482-490.

276. Fry P. Structured and unstructured reminiscence training and depression among the elderly. Clin Gerontol. 1983;1:15-37.

277. Perrotta P, Meacham J. Can a reminiscing intervention alter depression: nature, prevalence, and relationship to treatment response. Int J Aging Hum Dev. 1982;14:23-30.

278. Burns D. Feeling Good. New York: New American Library; 1980

279. Scogin F, McElreath L. Efficacy of psychosocial treatments for geratric depression: a quantitative review. J Consult Clin Psychol. 1994;57: 69-73.

280. Scogin F, Hamblin D, Beutler L. Bibliotherapy for depressed older adults: a self-help alternative. Gerontologist. 1987;27:383-387.

281. Scogin F, Jamison C, Davis N. Two-year follow-up of bibliotherapy for depression in older adults. J Consult Clin Psychol. 1990;58:665667.

282. Jamison $\mathrm{C}$, Scogin F. The outcome of cognitive bibliotherapy with depressed adults. J Consult Clin Psychol. 1995;63:644-650.

283. Saiger G. Group psychotherapy with older adults. Psychiatry. 2001; 64:132-145.

284. Rokke P, Tomhave J, Jocic Z. The role of client choice and target selection in self-management therapy for depression in older adults. Psychol Aging. 1999;14:155-169.

285. Jarvik L, Mintz J, Steuer J. Treating geriatric depression: a 26-week interim analysis. J Am Geriatr Soc. 1982;30:713-717. 
286. Steuer J. Cognitive-behavioral and psychodynamic group psychotherapy in treatment of geriatric depression. J Consult Clin Psychol. 1984; 52:180-189.

287. Lynch T, Morse J, Mendelson T. Dialectical behavior therapy in depressed elderly. Am J Geriatr Psychiatr. In press.

288. Lenze E, Dew M, Mazumba S, et al. Combined pharmacological and psychotherapy as maintenance treatment for late-life depression: effects on social adjustment. Am J Psychiatr. 2002;159:466-468.

289. Mulsant B, Alexopoulos G, Reynolds CR, et al. Pharmacological treatment of depression in older primary care patients: the PROSPECT algorithm. Intl J Geriatr Psychiatr. 2001;16:585-592.

290. Szanto K, Mulsant B, Houck P, Miller M, Mazumdar S, Reynolds C. Treatment outcome in suicidal vs. non-suicidal elderly patients. Am J Geriatr Psychiatr. 2001;9:261-268.
291. Blazer D. Self-efficacy and depression in late life: a primary prevention proposal. Aging Mental Health. 2002;6:319-328.

292. Alexopoulos G. New concepts for prevention and treatment of late life depression. Am J Psychiatr. 2001;158:835-838.

293. Rybarczyk B, De Marco G, DeLa Cruz M, Lapidos S. Comparing mind-body wellness interventions for older adults with chronic illness: classroom versus home instruction. Behav Med. 1999;24: 181-190.

294. Reynolds III C, Charney D. Editorial: unmet needs in the diagnosis and treatment of mood disorders in late life. Biol Psychiatr. 2002; 52:146.

295. Putnam R. Bowling Alone. New York: Simon \& Schuster; 2000.

Received September 27, 2002

Accepted October 4, 2002 